CALIFORNIA PATH PROGRAM

INSTITUTE OF TRANSPORTATION STUDIES

UNIVERSITY OF CALIFORNIA, BERKELEY

\title{
Factors Influencing Productivity and Operating Cost of Demand Responsive Transit
}

Kurt Palmer, Maged Dessouky, Zhiqiang Zhou

\author{
California PATH Research Report \\ UCB-ITS-PRR-2008-20
}

This work was performed as part of the California PATH Program of the University of California, in cooperation with the State of California Business, Transportation, and Housing Agency, Department of Transportation, and the United States Department of Transportation, Federal Highway Administration.

The contents of this report reflect the views of the authors who are responsible for the facts and the accuracy of the data presented herein. The contents do not necessarily reflect the official views or policies of the State of California. This report does not constitute a standard, specification, or regulation.

Final Report for Task Order 5403

October 2008

ISSN 1055-1425 



\title{
Factors Influencing Productivity and Operating Cost of Demand Responsive Transit
}

\author{
Final Project Report
}

\author{
Kurt Palmer \\ Maged Dessouky \\ Zhiqiang Zhou
}

\author{
Daniel J. Epstein Department of \\ Industrial and Systems Engineering \\ University of Southern California \\ Los Angeles, California 90089-0193
}

July 2005 



\section{Contents}

Abstract

$\begin{array}{ll}\text { Executive Summary } & \text { V }\end{array}$

1 Introduction $\quad 1$

2 The Implementation Survey $\quad 4$

2.1 Design of the Survey . . . . . . . . . . . . . . . . . . . . . . 4

2.2 Summary of Survey Responses . . . . . . . . . . . . . . . . . . . . . 7

3 Relationships between Operations and Performance 14

3.1 The Performance Data . . . . . . . . . . . . . . . . . . . . . . . . 14

3.2 Operations Variables . . . . . . . . . . . . . . . . . . . . 16

3.3 Analysis Results . . . . . . . . . . . . . . . . . . . . . . . . 21

4 Conclusions $r$

5 Acknowledgement $\quad 31$

$\begin{array}{ll}\text { A Surveyed Agencies } & 33\end{array}$

$\begin{array}{lr}\text { B Survey Form } & 39\end{array}$

$\begin{array}{ll}\text { C Responding Agencies } & 43\end{array}$

$\begin{array}{ll}\text { D Raw Survey Data } & 46\end{array}$ 



\section{List of Figures}

1 Clusters of Surveyed Agencies _. . . . . . . . . . . . . . . . . . 6

2 Operational Characteristics of Responding Agencies _ . . . . . . . . . . . . 10

3 Limits of the On-Time Window . . . . . . . . . . . . . . . . . . . 12

4 Time in Advance that Routes are Planned . . . . . . . . . . . . . . . . . . . 14

\section{List of Tables}

1 Responses by Segment . . . . . . . . . . . . . . . . . . . . 7

2 Operational Characteristics of Responding Agencies . . . . . . . . . . . 8

3 Management Practices Implemented by Responding Agencies . . . . . . . . . . . 9

4 Performance Measures Linked to Financial Clauses . . . . . . . . . . . . . . . . . 11

5 Advanced Technologies Implemented by Responding Agencies . . . . . . . . . . . 12

6 Use of Paratransit CAD systems . . . . . . . . . . . . . . . . . . . . . . 13

7 Operations Variables, Part $1 \ldots \ldots \ldots \ldots \ldots$

8 Operations Variables, Part $2 \ldots \ldots \ldots \ldots$

9 Operations Variables, Part $3 \ldots \ldots \ldots \ldots$

10 Passenger Miles per Vehicle Regression Results . . . . . . . . . . . . . . . . 21

11 Passenger Miles per Vehicle Regression Results . . . . . . . . . . . . . . . . . . 22

12 Passenger Trips per Vehicle Regression Results _ . . . . . . . . . . . . . . . . 25

13 Passenger Trips per Vehicle Regression Results . . . . . . . . . . . . . . . 25

14 Average Operating Cost Regression Results . . . . . . . . . . . . . . . 28

15 Average Operating Cost Regression Results . . . . . . . . . . . . . . . . 28 



\begin{abstract}
Since the enactment of the Americans with with Disabilities Act, in 1991, operating expenses for Demand Responsive Transit have more than doubled as demand for this mandated service has expanded. Many advanced technologies and management practices have been proposed and implemented to improve the efficiency of the service; but, evidence for the effectiveness of these actions has been based upon projections or small pilot studies. We present the results of a nationwide study involving 67 large transit agencies. We evaluate the impact of implemented technologies and practices upon productivity and operating cost.
\end{abstract}





\section{Executive Summary}

We have conducted a survey of transit agencies providing Demand Responsive Transit (DRT) service in medium sized and large urban centers throughout the United States. The survey has provided information regarding operational characteristics, management practices, and implementations of advanced technologies for 67 agencies that responded. We have evaluated the impact of the implemented technologies/practices on productivity and operating cost measures derived from information available in the 1997-2002 National Transit Database (NTD).

Our analysis indicates that use of a Paratransit CAD system to group service requests into vehicle routes provides a productivity benefit of approximately 12,000 passenger miles per vehicle, and 1,100 trips per vehicle, annually. However, there is no corresponding cost impact. These results suggest that policy makers should continue to implement Paratransit CAD systems, but should also monitor cost impacts that offset the expected benefits from productivity improvement.

The practice of manually revising routes during the time of service produces a detrimental impact on productivity of approximately 1,800 trips per vehicle annually. Policy makers should insist on some form of computational assistance for dispatchers, so that system-wide impacts of route revisions can be evaluated correctly in real time.

No-shows are identified as having a beneficial impact on productivity of approximately 10,500 passenger miles per vehicle annually. This is a misleading result that is produced by a deficiency in the Passenger Miles per Vehicle performance measure. Agencies should not attempt to increase their no-show rates. There is a need to identify more reliable measures of productivity that can be readily estimated.

The use of financial penalties was found to have benefical impacts on productivity and operating cost. This result is in conflict with the results of our previous study. We note that there are few agencies in common between the responders to the two surveys and attribute this apparent flip-flop in results to an as yet unidentified distinction between the two survey groups.

The portion of productivity performance variability explained by surveyed variables has increased substantially from the $10 \%$ level of the previous study. However, we stand at only about $40 \%$ of the productivity variability explained. The search to identify important variables related to operating cost has been less successful. Only about $10 \%$ of operating cost variability is explained, compared to about $5 \%$ previously. There is a need for further research to identify characteristics 

that determine performance. The recently announced request for proposals to the Transit Cooperative Research Program Project B-31, FY 2005, "Guidebook for Measuring, Assessing, and Improving Performance of Demand-Response Transportation", calls for research to identify both reliable metrics of performance and factors that affect performance of DRT systems. 



\section{Introduction}

Demand Responsive Transit (DRT) systems are the means by which 'comparable transportation services' are provided to mobility impaired individuals. The Americans with Disabilities Act (ADA) mandates that all transit agencies receiving federal funds must provide such services. Since the enactment of the ADA in 1991, DRT has expanded from a national total of 42.4 million passenger trips for the year to a total of 81.8 million passenger trips in 2003. Over the same period, the annual operating expense for DRT has gone from less than $3 \%$ to more than $7 \%$ of the total for public transportation services nationally, becoming a $\$ 1.7$ billion industry in 2003 (Federal Transit Administration 2003).

In the last fourteen years, many advanced technologies have been proposed to improve the performance of DRT systems, some have achieved substantial levels of implementation. The use of Advanced Communications systems has expanded to $45 \%$ of agencies that operate in the 78 largest metropolitan areas of the country (Volpe National Transportation Systems Center 2002). Paratransit Computer Aided Dispatching (CAD) systems are used by $34 \%$ of the agencies and Automated Vehicle Location systems are used by $28 \%$ of the agencies. (Our results show much higher percentages, see Table 5, probably due to the passage of 3 additional years.) Implementations of other Advanced Public Transportation Systems (APTS) technologies are less widespread. In addition to technological implementations, a variety of management practices such as type of service, use of financial penalties/incentives for performance, and use of ridesharing have been implemented as methods to influence productivity and operating costs.

There have been studies that investigate the impact of APTS on service productivity and cost. Computers and advanced algorithms were offered to improve the dispatching and scheduling of paratransit systems (Stone, Nalevanko, and Gilbert 1994). A study sponsored by the U. S. Department of Transportation quantified expected benefits of APTS based on future forecasts (Goeddel 1996). A survey of paratransit customers in southeastern Michigan concluded that APTS has ample potential to increase customer satisfaction when reserving a trip (Wallace 1997). A study in Santa Clara County, California, reported the productivity gains realized by of use of APTS technology (Chira-Chavala and Venter 1997). The implementation of Automatic Vehicle Location (AVL) and advanced scheduling was credited as the primary factor in increasing efficiency 
by $10.3 \%$ for Houston's METROLift Service (Higgins, Laughlin, and Turnbell 2000).

The potential and actual impact of management practices on DRT productivity and operating costs have also been reported. There are numerous paratransit delivery methods such as single contracts, multiple contracts, or direct service (Simon 1998). A Federal Transit Administration Study found that $7.6 \%$ of total expenditures by transit operators was spent on purchased transportation (Gilbert and Cook 1999). A case study in Portland, Oregon, showed that the service cost for demand responsive transit decreased by a half when switching from direct service to contract service, primarily due to labor cost differences (Rufolo, Strathman, and Peng 1997). However, each of these studies is limited by the fact that the evidence for the effectiveness of the technologies and practices considered is based either upon projections of future performance or observations of actual performance for a small number of agencies.

Under a grant from PATH (Dessouky, Palmer, and Abdelmaguid 2003; Palmer, Dessouky, and Abdelmaguid 2004), we conducted a nationwide benchmarking study involving an analysis of data from 62 transit agencies serving large and medium sized urban areas. Our intent was to evaluate the impact of several advanced technologies and management practices upon the productivity and operating cost of DRT systems. The advanced technologies that we considered included advanced communications, automated vehicle location, automated fare payment, automated transit information, and paratransit CAD systems. The management practices that we considered included financial incentives, financial penalties, ridesharing, agency administration, contracted administration, agency service delivery, contracted service delivery, and consumer choice.

We evaluated the impact of the implemented technologies/practices on productivity and operating cost measures derived from information available in the 1997-1999 National Transit Database (NTD). Our analysis indicated that use of a Paratransit CAD system provides a productivity benefit of approximately 12000 passenger miles per vehicle annually. Agency Service Delivery was also found to have a beneficial impact on productivity of approximately 1300 passenger trips per vehicle annually. The use of Advanced Communications technology was found to have a beneficial impact on operating cost of approximately $\$ 3.00$ per passenger trip in 1998. The use of Financial Incentives was found to have a detrimental impact on productivity of approximately 7000 passenger miles per vehicle annually. The use of Financial Penalties was found to have a detrimental impact on operating cost of approximately $\$ 2.00$ per passenger trip. 
The results of our previous study regarding the use of Paratransit CAD systems, and Financial Penalty and Incentive clauses, raised questions about the details of their use. In the case of Paratransit CAD systems, there are many operational functions that agencies might support or replace with this technology. In the case of Financial Penalty and Incentive clauses, the conditions that trigger activation of the clauses are unknown. In this report, we present the results of a new survey on advanced technology and management practice implementations. We received responses from 67 transit agencies that serve large and medium sized urban areas located throughout the United States. The responses provide a more detailed description of how CAD systems and financial clauses are used than has previously been available.

Among the agencies that participated in the previous study, 24 reported at least one new technology/practice implementation during the three-year period, 16 of those in 1999. As these implementations mature, their impact upon performance will become more evident. At the inception of the current study, data from the 2000-2002 NTD had become available. We combine the implementation information from our new survey with performance data from 1997-2002 to present an updated analysis of the relationships between technologies/practices and performance.

While each of the relationships identified in our previous study is statistically significant, they collectively explain only a small fraction of the observed variation in the performance measures. The list of technologies/practices that we considered in our previous work was selected through a review of the existing literature and our own knowledge of transit systems. In order to expand the list of factors under consideration, our new survey solicited the experience and expertise of transit agency personnel to identify factors not previously considered that may be explanatory of DRT system performance. Our updated performance analysis includes these newly identified factors; and consequently, we have been able to explain a substantially greater fraction of the observed variation than previously was the case.

The remainder of the report is organized in the following way. In Section 2, we describe the survey itself and summarize the responses received. In Section 3, we present the analysis relationships between operations variables derived from the survey and the performance data from the NTD. In Section 4, we summarize our conclusions from the analysis. 


\section{The Implementation Survey}

Data regarding the performance of DRT systems is available online from the NTD. The 2002 NTD lists 423 transit agencies that report providing a DRT service to their constituents. Of these agencies, 192 serve urban areas with a population of 200,000 or more. As in our previous study (Dessouky, Palmer, and Abdelmaguid 2003; Palmer, Dessouky, and Abdelmaguid 2004), we choose to focus on this group of 192 agencies for our survey because they provide the vast majority of DRT service. A list of the agencies surveyed appears in Appendix A.

\subsection{Design of the Survey}

The implementation survey had three objectives: (1) to obtain information regarding the state of implementation of advanced technologies and management practices, (2) to gather information about how CAD technology and financial clauses in service contracts are used, and (3) to gather information about other factors that might influence productivity and operating cost. We decided that closed format questions (multiple choice and fill-in the blank) would be most useful to keep the survey form short and facilitate the process of encoding responses for analysis. Even so, we wanted to access the experience of transit agency representatives in identifying factors that were not previously investigated by others or ourselves. To achieve this end, we decided to conduct interviews with a small number of agency representatives, as a means of brainstorming for questions to be included in the survey.

Interviews with representatives of Access Services, Inc. (Los Angeles, CA) and the Metropolitan Transit Authority of Harris County (Houston, TX) were conducted separately during the summer of 2004. The interview with Access Services was performed at their operations office. The interview with MTA of Harris County was performed by telephone. Attempts were made to interview a diverse group of agencies who had responded to our previous survey. We sent requests for interviews to five other agencies; but, we did not receive a response from them.

The interviews typically included a discussion of the procedures used to book a trip request, to schedule routes for the vehicles, and to service the requested trips. Follow-up questions delved into methods of handling schedule revisions and relationships with contractors. Confirmation of the current state of technology and management practice implementation was sought. Finally, 
open-ended questions were asked about any operational characteristics that experience indicated would have impact on productivity and operating cost.

Copious notes of the agency representatives' comments were taken during the interview sessions. These notes were reviewed afterwards to identify common themes in methodology used by the agencies and key characteristics that might be determinative of performance. The information gleened through these reviews became the basis for development of the new survey, which appears in the Appendix B.

The initial distribution of the survey was conducted via the U. S. Postal Service. Survey forms were mailed during the third week of February 2005 and agencies were requested to reply to the survey by March 11, 2005. Follow-up contact with non-responsive agencies was conducted via electronic mail. By the end of April 2005, we had received responses from 67 agencies.

Because self-selecting respondents can produce biased survey results, we decided to segment the surveyed agencies according to industry demographic variables and focus our e-mail follow-up activities on obtaining responses from agencies belonging to under-represented segments. The demographic variables that we selected are the Population Density of the urban area serviced by an agency and the Passenger Trips per Capita. The Population Density is determined as the ratio of the population to the square miles for the agency's service area. Passenger Trips per Capita is the ratio of unlinked passenger trips for the DRT service to the population of the service area. We use data from the 2002 NTD to estimate these quantities.

Figure 1 shows the results of a cluster analysis for the surveyed agencies' demographic variables. We performed a similar analysis for our previous study (Dessouky, Palmer, and Abdelmaguid 2003; Palmer, Dessouky, and Abdelmaguid 2004). In that case, the clusters were formed using the average linkage method of agglomerative hierarchical clustering (Massart and Kaufman 1983, SAS Institute 1988). For this analysis, we wanted to retain clusters with similar average characteristics to those identified before. Consequently, the list of surveyed agencies was divided into those who had been surveyed before and those who were newly listed. If an agency appeared on the list before, and its demographic characteristics remained similar to before, its cluster assignment was retained. The agencies with retained assignments were then used to calculate the average Population Density and Trips per Capita (the centroid coordinates) for each cluster. Newly listed agencies, and agencies with substantially changed characteristics, were assigned to the cluster 


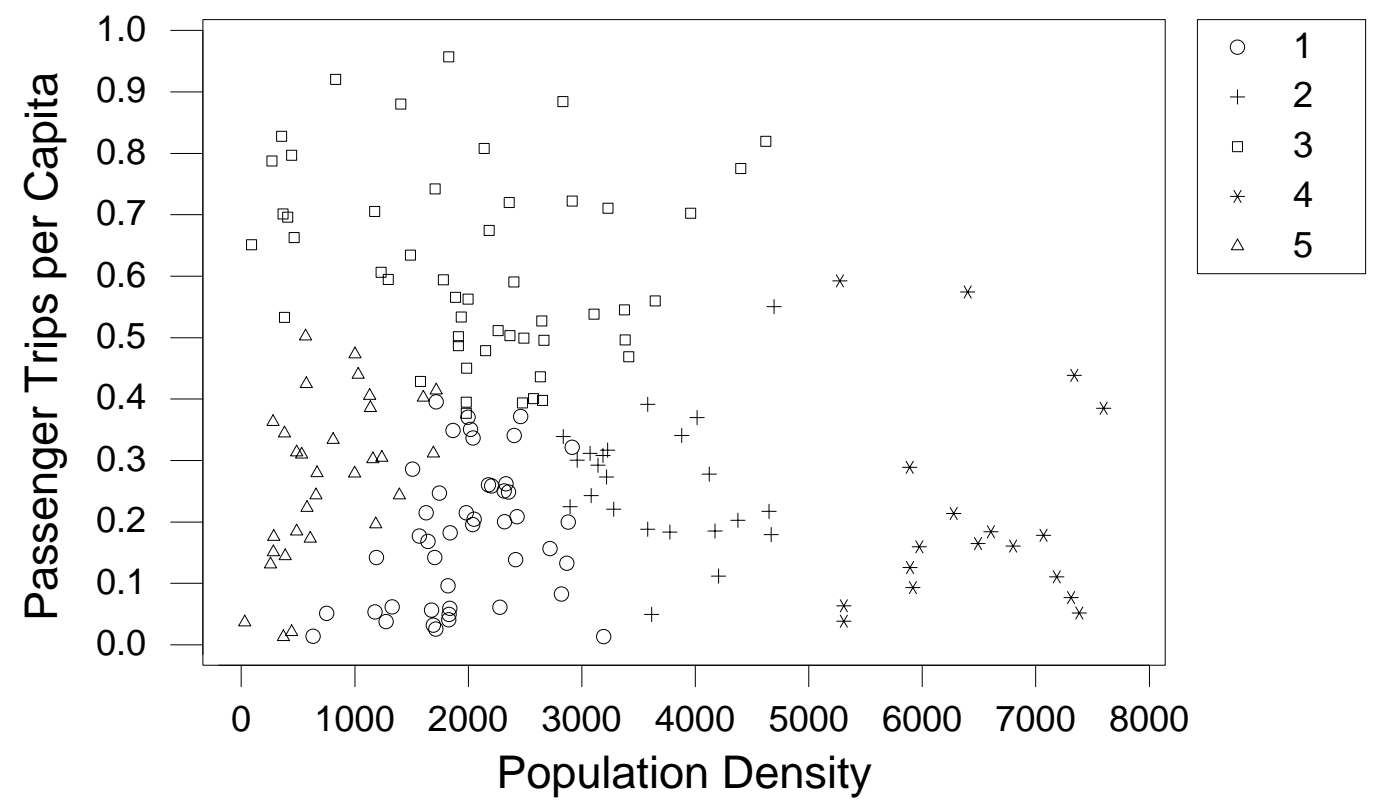

Figure 1: Clusters of Surveyed Agencies

whose centroid was closest. A Euclidian distance based upon values of the demographic variables that had been scaled by their respective standard deviation was used for the evaluation.

As in the previous study, there is a group of some 18 agencies that are considered outliers for the cluster analysis: 11 agencies have ridership greater than 0.99 Passenger Trips per Capita and 7 agencies serve areas with Population Density greater than 8000 persons per square mile. These 18 outliers are not represented in Figure 1, but are used throughout the rest of the current study. On the other hand, it was discovered that there is a group of 6 agencies among those surveyed that do not show reported values for the performance measures to be evaluated below, nor can they be tied via a contractual relationship to an agency that does report performance data. These 6 agencies (TRS ID: 1102, 4034, 9003, 9014, 9015, 9129) were removed from further consideration.

Table 1 shows the number of surveyed agencies in each of the demographic segments. Our goal for the survey was to achieve a $30 \%$ response rate, both overall and for each segment. By focusing the e-mail follow-up messages to agencies in under-represented segments, we were able to achieve our response rate goal. A list of the responding agencies appears in Appendix C. 


\subsection{Summary of Survey Responses}

In the first portion of the survey, we asked agencies to provide information about a series of operational characteristics. Most of these questions regarded policies and procedures that are general to the DRT service. Table 2 summarizes the responses to the yes/no and multiple choice questions in this portion of the survey. It is noteworthy that among the 49 agencies that indicate they send a letter to customers who produce no-shows, 18 agencies also indicate that there is a possibility of suspension of service for customers that produce frequent no-shows. Among the 10 agencies that indicate customers are impacted in some way other than a phone call or letter, 7 agencies employ a suspension policy and 3 agencies assess fees.

Six of the questions in the operational characteristics portion of the survey requested numerical information. Histograms of the responses to these questions are shown in Figure 2. Agencies that indicate they use zones within their service area to restrict pick-up locations for providers were asked to also indicate how many zones are used, Figure 2 (a). Among the 65 agencies that accept advanced reservations, 3 agencies did not indicate the longest notice for which a reservation would be accepted. The most common answers among the 62 agencies that did respond are 7 days and 14 days, Figure 2 (b). Among the 29 agencies that accept same-day reservations, 8 did not indicate the shortest notice for which a reservation would be accepted. The most common answer among the 21 agencies that did respond was a time less than 1 hour, Figure 2 (c). The most common responses to the question regarding percentage of requests that are handled by directly operated vehicles are 'none' and 'all' (6 agencies did not respond), Figure 2 (d). For the 56 agencies that responded to the question regarding percentage of requests that are cancelled, the mean is $11 \%$ and the standard deviation is $6.8 \%$, Figure 2 (e). Finally, for the 57 agencies that responded to the question regarding percentatge of requests that produce no-shows, the mean is $4.3 \%$ and the

Table 1: Responses by Segment

\begin{tabular}{lrr}
\hline Segment & Surveyed & Responses \\
\hline Cluster 1 & 45 & 20 \\
Cluster 2 & 23 & 8 \\
Cluster 3 & 51 & 16 \\
Cluster 4 & 18 & 6 \\
Cluster 5 & 31 & 12 \\
Outliers & 18 & 5 \\
\hline
\end{tabular}


Table 2: Operational Characteristics of Responding Agencies

\begin{tabular}{|c|c|c|c|}
\hline Yes/No Questions - & Yes & No & $\mathrm{N} / \mathrm{A}$ \\
\hline \multicolumn{4}{|l|}{ Is your service area divided into zones that limit } \\
\hline where a particular provider may pick-up a customer? & 12 & 54 & 1 \\
\hline Is scheduling coordinated across the zones? & 10 & 2 & 55 \\
\hline Do you accept standing reservations? & 58 & 8 & 1 \\
\hline Do you accept advanced reservations? & 65 & 2 & 0 \\
\hline Do you handle same-day requests? & 29 & 36 & 2 \\
\hline \multicolumn{4}{|l|}{$\begin{array}{l}\text { Do you accept requests for travel outside the boundaries } \\
\text { of the local fixed-route bus service? }\end{array}$} \\
\hline \multicolumn{4}{|l|}{ Multiple Choice Questions - } \\
\hline \multicolumn{4}{|l|}{ On what basis are contractors paid? } \\
\hline Service requests only & 8 & & \\
\hline Service hours only & 24 & & \\
\hline Service mileage only & 4 & & \\
\hline Requests and Hours & 3 & & \\
\hline Requests and Mileage & 1 & & \\
\hline Hours and Mileage & 5 & & \\
\hline All & 1 & & \\
\hline Other & 2 & & \\
\hline $\mathrm{N} / \mathrm{A}$ & 19 & & \\
\hline \multicolumn{4}{|l|}{ Are drivers considered employees or independent contractors? } \\
\hline Employees & 30 & & \\
\hline Independent Contractors & 23 & & \\
\hline Both & 12 & & \\
\hline $\mathrm{N} / \mathrm{A}$ & 2 & & \\
\hline \multicolumn{4}{|l|}{ How are customers impacted when they produce no-shows? } \\
\hline No impact & 4 & & \\
\hline Phone call & 3 & & \\
\hline Letter & 41 & & \\
\hline Phone call and Letter & 8 & & \\
\hline Other & 10 & & \\
\hline $\mathrm{N} / \mathrm{A}$ & 1 & & \\
\hline
\end{tabular}


Table 3: Management Practices Implemented by Responding Agencies

\begin{tabular}{lrrcccccccc}
\hline & \multicolumn{3}{c}{ Before } & \multicolumn{4}{c}{ Year Implemented } & \multicolumn{3}{c}{ After } \\
& No & Yes & 1997 & 1997 & 1998 & 1999 & 2000 & 2001 & 2002 & 2002 \\
\hline Financial Penalties & 33 & 34 & 22 & 1 & 0 & 2 & 2 & 2 & 2 & 3 \\
Financial Incentives & 44 & 23 & 12 & 0 & 0 & 0 & 1 & 3 & 3 & 4 \\
Ridesharing & 27 & 40 & 38 & 0 & 0 & 1 & 0 & 0 & 0 & 1 \\
Agency Administration & 9 & 58 & 47 & 5 & 1 & 1 & 3 & 1 & 0 & 0 \\
Contracted Administration & 39 & 28 & 26 & 0 & 0 & 1 & 1 & 0 & 0 & 0 \\
Consumer Choice & 61 & 6 & 3 & 0 & 0 & 1 & 1 & 0 & 0 & 1 \\
\hline
\end{tabular}

standard deviation is $4.3 \%$, Figure 2 (f).

There is one question in the operational characteristics portion of the survey that asked the agency to describe how reservations for return travel are dealt with when the outbound reservation produces a no-show. Among the 54 agencies that responded to the question, 20 indicate that they cancel the return trip, 25 indicate that they keep the return trip on the schedule, 7 indicate that they contact the customer, and 2 indicate that they take some other action.

In the second portion of the survey, we asked agencies to provide information about their management practices. The initial set of questions asked about whether or not the agency uses any of six specific practices. If an agency does use one or more of the practices, we also asked them to indicate the year that each practice was first implemented. This information is summarized in Table 3. In the table, we concentrate on implementation years corresponding to the performance data that we have from the NTD. This information will be useful below, when we identify relationships between implementation and performance.

Besides the initial set of questions, we also asked a series of questions designed to delve more deeply into the use of financial penalty and incentive clauses in contracts with service providers. Two of these questions asked agencies to indicate the performance measures that are linked to penalties and incentives. Four specific measures (on-time pick-ups, productivity, customer complaints, and driver turnover) were offered to the agencies as multiple choice selections. The agencies were then asked to list any additional measures that they use. Their responses are summarized in Table 4. The table shows the number of agencies that use any of the four specific measures as their sole performance measure. The table also shows the number of agencies that use just one of the specific measures along with other measures not specifically offered. The most commonly listed 
(a)

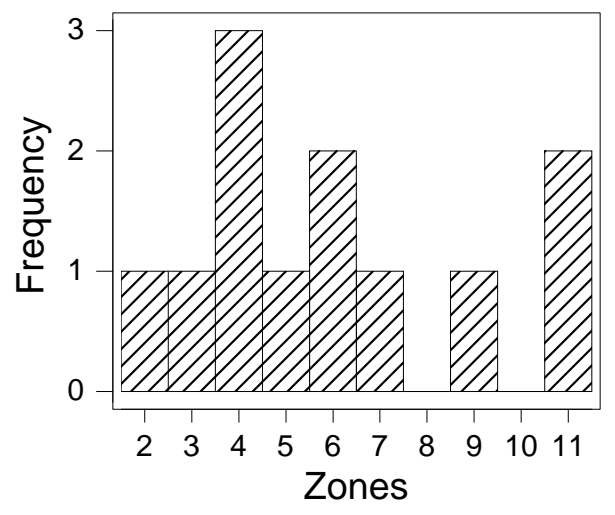

(c)

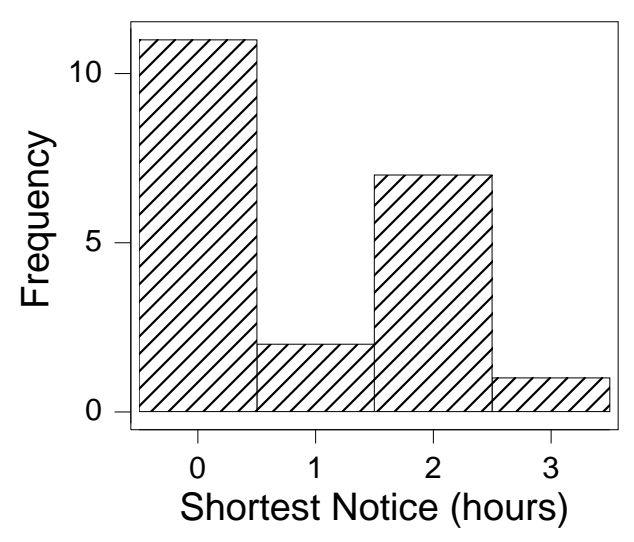

(e)

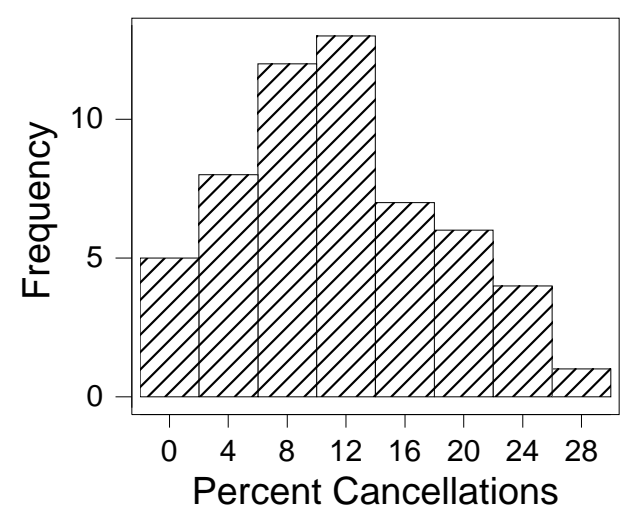

(b)

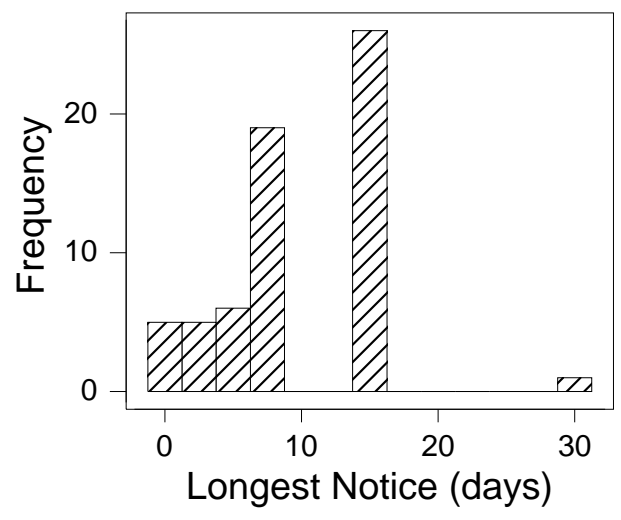

(d)

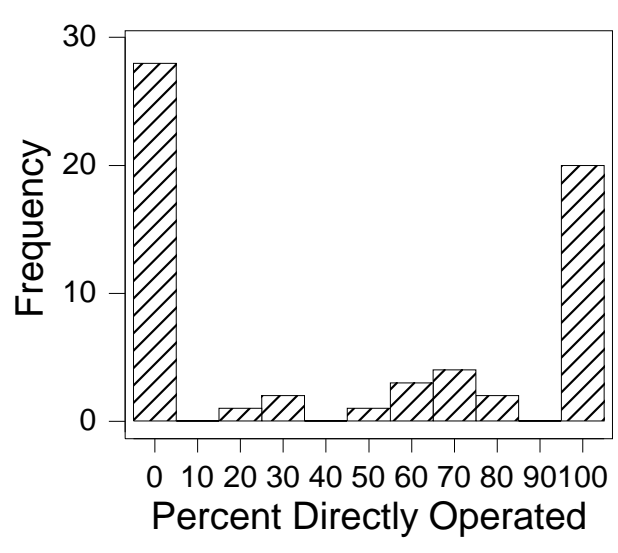

(f)

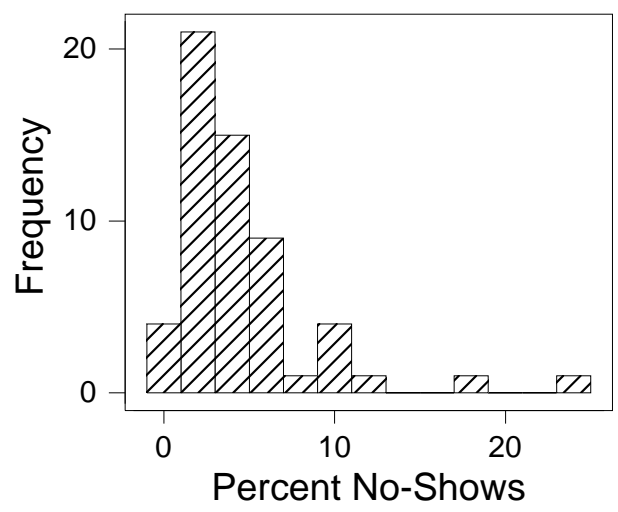

Figure 2: Operational Characteristics of Responding Agencies 
Table 4: Performance Measures Linked to Financial Clauses

\begin{tabular}{lrrrr}
\hline & \multicolumn{2}{c}{ Penalties } & \multicolumn{2}{c}{ Incentives } \\
& w/o Other & with Other & w/o Other & with Other \\
\hline 1) On-time pick-ups & 4 & 2 & 1 & 2 \\
2) Productivity & 3 & 0 & 3 & 0 \\
3) Customer complaints & 1 & 1 & 1 & 2 \\
4) Driver turnover & 1 & 0 & 0 & 0 \\
(1) and (2) & 3 & 1 & 1 & 2 \\
(1) and (3) & 5 & 2 & 0 & 1 \\
(1) and (4) & 1 & 0 & 0 & 0 \\
(1), (2), and (3) & 1 & 2 & 1 & 3 \\
(1), (2), and (4) & 0 & 1 & 0 & 1 \\
Other only & 2 & & 2 & \\
N/A & 4 & & 3 & \\
\hline
\end{tabular}

other measures that agencies use include: no-show rates, vehicle maintenance history, accident history, and telephone response time. Lastly, the table shows the number of agencies that use combinations of the specific measures, either as the sole measures or in combination with other measures not specifically offered.

We also asked the agencies how often they assess penalties or award incentives. Among the 34 agencies that indicate they use financial penalties, 18 agencies assess the penalties monthly and 12 agencies did not respond. Among the 23 agencies that indicate use of financial inventives, 11 agencies award the incentives monthly and 8 agencies did not respond.

Our final question in the management practices portion of the survey asked agencies to give their definitions of the on-time window. Table 4 shows that 22 of 34 agencies use on-time pickups as one of the performance measures linked to financial penalties, and 12 of 23 agencies link on-time pick-ups to financial incentives. Figure 3 shows histograms of the responses for the limits of the on-time window. For the 59 agencies that indicate an earliest arrival time before the requested pick-up, half of the agencies use 15 minutes and most of the others use a shorter time, Figure 3 (a). For the 64 agencies that indicate a latest arrival time after the requested pick-up, half of the agencies use 15 minutes and most of the others use either 20 or 30 minutes, Figure 3 (b).

In the third and last portion of the survey, we asked agencies to provide information about their use of advanced technologies. The initial set of questions asked whether or not the agency uses any of five specific technologies. Here again, if the agency indicates usage of a technology, 
(a)

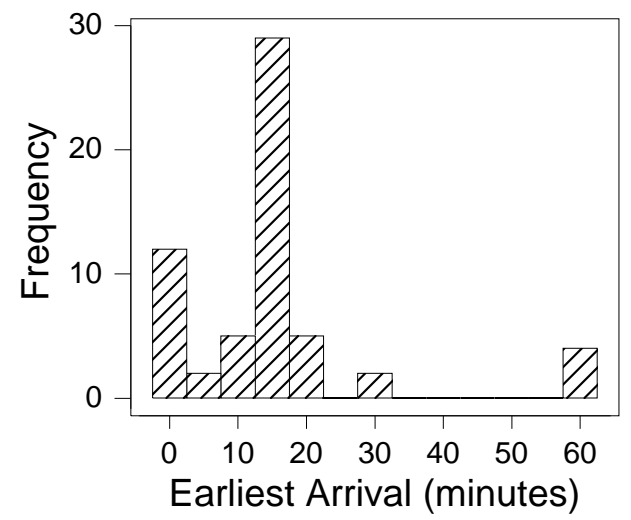

(b)

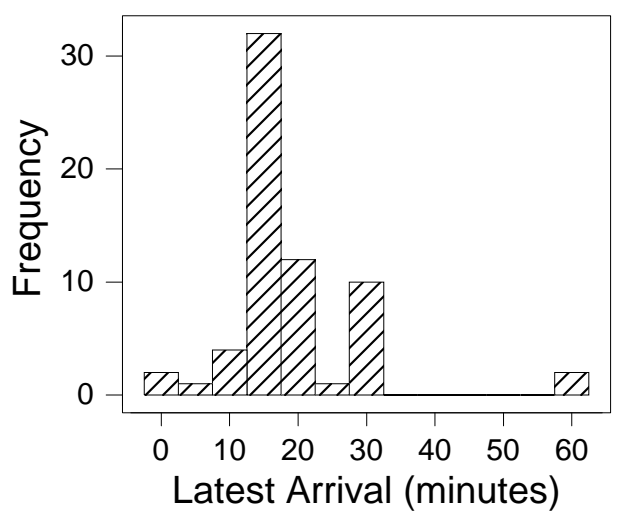

Figure 3: Limits of the On-Time Window

Table 5: Advanced Technologies Implemented by Responding Agencies

\begin{tabular}{lccccccccccc}
\hline & \multicolumn{1}{c}{ Before } & \multicolumn{1}{c}{ Year Implemented } & \multicolumn{3}{c}{ After } \\
& No & Yes & 1997 & 1997 & 1998 & 1999 & 2000 & 2001 & 2002 & 2002 \\
\hline Advanced Communications & 21 & 46 & 28 & 3 & 1 & 3 & 2 & 7 & 0 & 2 \\
Automated Vehicle Location & 37 & 30 & 5 & 0 & 0 & 3 & 3 & 10 & 1 & 8 \\
Automated Fare Payment & 61 & 6 & 0 & 0 & 0 & 0 & 1 & 3 & 0 & 2 \\
Automated Transit Information & 59 & 8 & 0 & 0 & 1 & 0 & 0 & 2 & 0 & 5 \\
Paratransit CAD System & 13 & 54 & 25 & 2 & 3 & 4 & 6 & 9 & 0 & 5 \\
\hline
\end{tabular}

we also asked them to indicate the year of implementation. This information is summarized in Table 5.

We also asked a series of questions regarding details of the use of CAD systems. The agencies' responses are summarized in Table 6 . With regard to the period of time over which a route is planned, beyond the given options of full-day or half-day, agencies plan for full shifts or build routes in real-time. With regard to the number of requests given to a driver, agencies not using full-day or half-day will give a 1-2 hours or less than 5 trips. The amount of requests communicated is sometimes limited by the display capability of a mobile data terminal.

Last of all, we asked "How long in advance are routes planned?". Figure 4 shows a histogram of the responses. Among the 45 agencies that responded, more than half plan 1 day in advance. 
Table 6: Use of Paratransit CAD systems

\begin{tabular}{lr}
\hline How are service requests grouped into routes for each vehicle? & \\
Manually & 11 \\
Automatically, using CAD & 39 \\
Both & 15 \\
N/A & 2
\end{tabular}

If routes are created automatically, does dispatch staff revise the routes manually before use?

Yes

No

How are routes revised during the time of use?

Manually

Automatically, using CAD

Both

Other

$\mathrm{N} / \mathrm{A}$

Over what period of time is a route planned to occur?

Full-day

Half-day

Both

Other

$\mathrm{N} / \mathrm{A}$

What is the amount of requests given to a driver at one time?

Full-day

Half-day

One-at-a-time

Other

N/A 


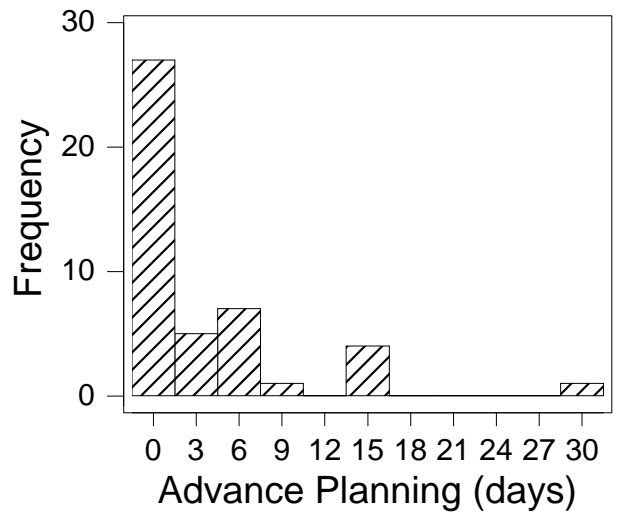

Figure 4: Time in Advance that Routes are Planned

\section{Relationships between Operations and Performance}

The survey responses from each agency provide a description of the operations of their DRT service. The National Transit Database (NTD) provides data that can be used to describe the performance of each agency's DRT service. We use regression models to identify relationships between the operations and the performance. The first step of the analysis is selection of the performance measures.

\subsection{The Performance Data}

In our previous work (Dessouky, Palmer, and Abdelmaguid 2003; Palmer, Dessouky, and Abdelmaguid 2004), we used the following performance measures

- Passenger Miles per Vehicle, PassMil/Veh

- Passenger Trips per Vehicle, Trip/Veh

- Operating Expense per Passenger Trip, OpExp/Trip

- Operating Expense per Passenger Mile, OpExp/PassMil 
These performance measures are constructed from data available for each agency in the annual NTD. Passenger miles are the total of distances traveled by each passenger. Passenger trips are the total of unlinked trips made by each passenger. The number of vehicles is the number reported as the maximum actually operated to provide service on an average weekday. Operating expense is the total of contracts for purchased transportation and expenses for directly operated DRT services.

The performance measures above were selected to represent the characterisitcs of productivity and opeating cost. Productivity is defined as output per unit input. Both output and input can be measured either in monetary or non-monetary terms. Traditional measures of productivity, such as economic value of services provided per labor hour, are inconvenient to use in this case because the economic value of DRT services is neither commonly reported nor easily estimated. The National Transit Summaries and Trends (NTST) report (Federal Transit Administration 2003) uses revenue hours as a non-monetary measure of output. The NTST report also offers passenger miles and passenger trips as examples of non-monetary measures of consumption. The distinction between consumption and output is a recognition that some output is not used by the customers.

For our measures of productivity, we prefer to focus on the utilized portion of output, measured by passenger miles and passenger trips. Since we are examining operating cost as a separate perfomance characteristic, we choose to use number of vehicles as a non-monetary measure of input. For our measures of operating cost, it is appropriate to use cost per unit output so that services of varying scale may be compared. It should also be noted that, in our analysis, operating expenses have been inflation adjusted to constant 1999 dollars.

Ideally, each measure should represent an independent performance characteristic. To investigate this issue for the measures described above, a principal components analysis (Johnson and Wichern 1992) was performed separately for each year of NTD data (1997 through 2002). Data for all agencies in the survey group was used. The six analyses produced consistent results. The results reveal that these measures are most naturally arranged into two groupings. The first group, consisting of PassMil/Veh and Trip/Veh, represents one characteristic that we interpret to be productivity. The second group, consisting of OpExp/PassMil and OpExp/Trip, represents another characteristic that we interpret to be operating cost. However, these two characterisitcs are not independent. They have a weak negative correlation with each other. Agencies that have high 
productivity also tend to have low operating cost, and visa versa.

The two measures within each grouping are positively correlated. The strongest positive correlation is that between OpExp/PassMil and OpExp/Trip. Since we could devise no individual interpretation for these measures, nor a reason to prefer one over the other, we chose to define an Average Operating Cost $(A O C)$ measure, see Equation 1 for an example based on the 2002 data. The $A O C$ is formulated as the mean of the scaled performance measures. The values $\$ 20.630$ and $\$ 10.073$ are the mean and standard deviation of OpExp/Trip for the 186 agencies surveyed. The values $\$ 2.6126 /$ mile and $\$ 1.1854 /$ mile are the mean and standard deviation of OpExp/PassMil.

$$
A O C \equiv\left(\frac{\text { OpExp/Trip }-20.630}{10.073}+\frac{\text { OpExp/PassMil }-2.6126}{1.1854}\right) \div 2
$$

We interpret PassMil/Veh as being related to the portion of miles traveled by the vehicle that is productive. We refer to this characteristic as mileage productivity. We interpret Trip/Veh as being related to the number of passengers travelling simultaneously in the vehicle. We refer to this characteristic as people loading productivity. While the interpretation of these measures is inspired by the concepts of mileage productivity and people loading productivity, we must admit that neither measure can be said to represent solely one or the other characteristic. For example, PassMil/Veh can be increased by shortening trip segments when the vehicle carries no passengers, thereby allowing the vehicle to service more requests over the same number of total miles. But, PassMil/Veh can also be increased by carrying more than one passenger at a time,

thereby multiple counting the miles when the vehicle is carrying passengers. Similarly, one could argue that both effects can influence the Trip/Veh measure.

Having selected the performance measures, the next step is to define the operatons variables that are derived from the survey responses.

\subsection{Operations Variables}

A total of 28 operations variables have been defined to represent the responses given in the survey. Most of the operations variables, 24 in all, are defined as indicator variables. For each of these, the value 1 indicates that the characteristic in question is used and the value 0 indicates that the characteristic is not in use. The four remaining operations variables are defined as continuous 
values. Two of these are times expressed in days or minutes, respectively. The final two variables are percentages, actually proportions expressed as a value between 0 and 1 . Tables 7, 8, and 9 show the list of operations variables.

Two of the indicator variables, Directly Operated and Purchased Transport., are used to encode the answers to the survey question regarding the percentage of service requests handled by directly operated vehicles. As Figure 2 (d) shows, 19 of the agencies have 100\% directly operated (Directly Operated $=1$, Purchased Transport. $=0$ ), 28 agencies have $0 \%$ directly operated (Directly Operated $=0$, Purchased Transport. $=1$ ), and only 15 agencies have an intermediate result (5 agencies did not provide an answer). Given these results, the use of a continuous variable is unnecessary. Two indicators are used so that agencies having percentages between 0 and 100 may be represented appropriately. These indicators can also be verified by comparison to the NTD.

A concern regarding the creation of operations variables was that each of the indicators should offer a good split between the two outcomes. If an overwhelming majority of the responding agencies failed to display a particular characteristic, it would not be possible to evaluate the performance impact of the characteristic because there would be too little evidence of the performance in the presence of the characteristic. A similar problem would occur if an overwhelming majority of agencies displayed the characteristic. There would be too little evidence of the performance in the absence of the characterstic. Each of the indicators shown in Tables 7 and 8 has at least 8 agencies represented in each outcome.

Some characteristics that were investigated in the survey did not produce enough agencies that displayed the characteristic to warrant an operational variable for the characteristic. The Consumer Choice management practice had only 5 responding agencies who had implemented the practice during the 1997-2002 performance window, see Table 3. The Automated Fare Payment technology was only implemented by 4 agencies and the Automated Transit Information technology was only implemented by 3 agencies, see Table 5 .

A second concern about the operations variables was that they should be nearly independent of each other. If a large portion of the responding agencies display two characteristics concurrently, then it is not possible to separate the impacts of the two on performance via the regression techniques that we use. A correlation analysis (Draper and Smith 1981) of the operations variables was performed to identify any characteristics that tend to be concurrently displayed. 
Table 7: Operations Variables, Part 1

\begin{tabular}{|c|c|}
\hline Variable & Question/Measure \\
\hline \multicolumn{2}{|l|}{ Indicator Variables } \\
\hline Zones & $\begin{array}{l}\text { Is your service area divided into zones that limit where } \\
\text { a particular provider may pick-up a customer? }\end{array}$ \\
\hline Standing Reservation & Do you accept standing reservations? \\
\hline Same Day & Do you handle same-day requests? \\
\hline Outside & $\begin{array}{l}\text { Do you accept requests for travel outside the boundaries } \\
\text { of the local fixed-route bus service? }\end{array}$ \\
\hline Directly Operated & $\begin{array}{l}\text { What percentage of service requests does your agency } \\
\text { handle by directly operated vehicle? }\end{array}$ \\
\hline Purchased Transport. & $\begin{array}{l}\text { What percentage of service requests does your agency } \\
\text { handle by directly operated vehicle? }\end{array}$ \\
\hline Service Requests & $\begin{array}{l}\text { On what basis are contracted providers paid? - service } \\
\text { requests }\end{array}$ \\
\hline Service Hours & $\begin{array}{l}\text { On what basis are contracted providers paid? - service } \\
\text { hours }\end{array}$ \\
\hline Service Mileage & $\begin{array}{l}\text { On what basis are contracted providers paid? - service } \\
\text { mileage }\end{array}$ \\
\hline Financial Incentives & $\begin{array}{l}\text { Payments to contractors, in addition to the base fee, } \\
\text { that are contingent upon service performance results }\end{array}$ \\
\hline Ridesharing & $\begin{array}{l}\text { A vehicle simultaneously serves trip requests from more } \\
\text { than one customer by use of a carpooling strategy }\end{array}$ \\
\hline Agency Admin. & $\begin{array}{l}\text { The agency named on the survey performs the following } \\
\text { functions: determines ADA eligibility, arranges for use } \\
\text { of vehicles and services of drivers, monitors service per- } \\
\text { formance, and distributes funds in payment for trans- } \\
\text { portation }\end{array}$ \\
\hline Contracted Admin. & $\begin{array}{l}\text { The agency named on the survey contracts another or- } \\
\text { ganization(s), most likely a private operator, to perform } \\
\text { the functions listed above }\end{array}$ \\
\hline
\end{tabular}


Table 8: Operations Variables, Part 2

\begin{tabular}{|c|c|}
\hline Variable & Question/Measure \\
\hline \multicolumn{2}{|l|}{ Indicator Variables (cont.) } \\
\hline On-time & $\begin{array}{l}\text { What performance measures does your agency link to } \\
\text { financial penalties? - on-time pick-ups }\end{array}$ \\
\hline Productivity & $\begin{array}{l}\text { What performance measures does your agency link to } \\
\text { financial penalties? - productivity }\end{array}$ \\
\hline Complaints & $\begin{array}{l}\text { What performance measures does your agency link to } \\
\text { financial penalties? - customer complaints }\end{array}$ \\
\hline Other & $\begin{array}{l}\text { What performance measures does your agency link to } \\
\text { financial penalties? - other }\end{array}$ \\
\hline Adv. Communications & $\begin{array}{l}\text { A digital radio or wireless personal communication sys- } \\
\text { tem used to transmit voice and/or data between the } \\
\text { vehicle and the dispatch center }\end{array}$ \\
\hline Auto. Vehicle Location & $\begin{array}{l}\text { A computer-based tracking system that includes a } \\
\text { method of determining vehicle location (such as global } \\
\text { positioning system, active signposts, ground-based ra- } \\
\text { dio) and a method of transmitting data from the vehicle } \\
\text { to the dispatch center }\end{array}$ \\
\hline Auto. Grouped & $\begin{array}{l}\text { How are service requests grouped into routes for each } \\
\text { vehicle? - automatically, by using a CAD software }\end{array}$ \\
\hline Manual Grouped & $\begin{array}{l}\text { How are service requests grouped into routes for each } \\
\text { vehicle? - manually }\end{array}$ \\
\hline Auto. Revised & $\begin{array}{l}\text { How are routes revised during the time of use? - auto- } \\
\text { matically, by using a CAD software }\end{array}$ \\
\hline Manual Revised & $\begin{array}{l}\text { How are routes revised during the time of use? - man- } \\
\text { ually }\end{array}$ \\
\hline Planning Period & $\begin{array}{l}\text { Over what period of time is a route planned to occur? } \\
\text { - full-day }\end{array}$ \\
\hline
\end{tabular}


Table 9: Operations Variables, Part 3

\begin{tabular}{ll}
\hline Variable & Question/Measure \\
\hline Lontinuous Variables & $\begin{array}{l}\text { Longest number of days advanced notice that a cus- } \\
\text { tomer may request a pick-up }\end{array}$ \\
\%Cancelled & $\begin{array}{l}\text { Percentage of service requests that customers cancel af- } \\
\text { ter routes are planned }\end{array}$ \\
\%No-shows & $\begin{array}{l}\text { Percentage of service requests that customers fail to } \\
\text { show for the pick-up }\end{array}$ \\
Latest Arrival & $\begin{array}{l}\text { Latest arrival time after requested pick-up that is con- } \\
\text { sidered on-time, in minutes }\end{array}$ \\
\hline
\end{tabular}

The correlation analysis revealed that Financial Incentives are concurrent with the On-time, Complaints, and Other indicators. These indicators represent performance measures that are linked to financial penalties. All agencies that implement financial incentives also implement financial penalties. As a result, it is not possible for us to determine the impact of using financial incentives in the absence of financial penalties. The On-time indicator is also correlated with the Productivity and Complaints indicators. See Table 4 for a detailed description of the concurrent usage of these measures.

There is a relationship between the use of Automated Vehicle Location technology and the practice of Manually Grouping service requests into routes. Agencies that have AVL technology do not use manual grouping. As a result, it is not possible for us to determine the impact of using manual grouping in the presence of AVL technology.

A final issue connected to operations variables is the timing of management practice and technology implementations. If a practice/technology was implemented during the time frame of our performance evaluation, the performance measures reported during the transition could not be considered to be representative of typical pre- or post-implementation performance. Consequently, if a practice/technology was implemented within the 1997-2002 time frame, the performance measures for the year of implementation were removed from the analysis. Tables 3 and 5 show the amount of data loss for this cause. 
Table 10: Passenger Miles per Vehicle Regression Results

\begin{tabular}{l|rr|rr|rr}
$y$ : $(\text { ScaledMiles }+3)^{0.75}$ & \multicolumn{10}{c}{1998} & \multicolumn{3}{c}{1999} \\
& \multicolumn{3}{|c}{1997} & & \multicolumn{1}{c}{} \\
Term & Coeff. Est. & p-value & Coeff. Est. & p-value & Coeff. Est. & p-value \\
\hline Auto. Grouped & 0.35 & 0.035 & 0.35 & 0.033 & 0.62 & 0.000 \\
\%No-shows & - & - & - & - & 5.37 & 0.013 \\
Complaints & - & - & 0.60 & 0.001 & - & - \\
Productivity & - & - & 0.37 & 0.022 & - & - \\
Other & - & - & 0.33 & 0.017 & 0.35 & 0.006 \\
\%Cancelled & 2.11 & 0.019 & - & - & - & - \\
Zones & -0.33 & 0.033 & - & - & - & - \\
& & & & & & \\
R-sq(adj) & $28 \%$ & & $37 \%$ & & $40 \%$ & \\
\hline
\end{tabular}

\subsection{Analysis Results}

We began by analyzing relationships to the PassMil/Veh productivity measure. Linear regression techniques were used to evaluate the statistical significance of the relationships between PassMil/Veh and the operations variables. The first step was to scale the measure using its mean and standard deviation, see Equation 2 for the 2002 data example. A Box-Cox power transformation (Draper and Smith 1981, Myers and Montgomery 1995) was applied to the scaled measure to improve the normality of the regression residuals. Separate maximum likelihood estimates of the power transformation exponent were calculated for each year of NTD data. The estimates were found to be consistent; so, a single value for the exponent $(\lambda=0.75)$ was selected for uniform application across all years of NTD data. Finally, a stepwise regression procedure was used to select the terms in the model for each year. Tables 10 and 11 show the results of the regression analysis. The tables show all model terms found significant at the $4 \%$ level. Since the purpose of these models is to identify statistically significant relationships between PassMil/Veh and the operations variables, the intercept estimates are omitted from the tables.

$$
\text { ScaledMiles }=\frac{\text { PassMil } / \text { Veh }-38455}{18834}
$$

The most consistent relationship to PassMil/Veh is with the use of Paratransit CAD technology to automatically group trip requests into routes. This relationship is observed in all years except 2001. The sense of the relationship is positive. Agencies that Auto. Grouped have a greater 
Table 11: Passenger Miles per Vehicle Regression Results

\begin{tabular}{|c|c|c|c|c|c|c|c|c|c|}
\hline \multirow[b]{2}{*}{ Term } & \multicolumn{3}{|c|}{2000} & \multicolumn{3}{|c|}{2001} & \multicolumn{3}{|c|}{2002} \\
\hline & Coef & Est. & $\mathrm{p}$-value & Coeff & Est. & $\mathrm{p}$-value & Coeff. & Est. & $\mathrm{p}$-value \\
\hline Auto. Grouped & & 0.83 & 0.004 & & - & - & & 0.45 & 0.009 \\
\hline Manual Revised & & - & - & & -1.11 & 0.000 & & - & - \\
\hline$\% \mathrm{No}-$-shows & & 16.50 & 0.000 & & 7.28 & 0.004 & & 4.85 & 0.001 \\
\hline Productivity & & - & - & & 0.59 & 0.002 & & - & - \\
\hline Other & & - & - & & - & - & & 0.41 & 0.004 \\
\hline Service Mileage & & - & - & & -0.40 & 0.025 & & — & - \\
\hline$R-s q(a d j)$ & & $39 \%$ & & & $66 \%$ & & & $36 \%$ & \\
\hline
\end{tabular}

PassMil/Veh value than agencies that do not. For the 1997 data, responding agencies that Auto. Grouped had a mean PassMil/Veh value of 37200 miles/vehicle, while the responding agencies that had not Auto. Grouped technology had a mean value of 27700 miles/vehicle. For 1998, the mean values are 37500 miles/vehicle for Auto. Grouped versus 27600 miles/vehicle for not Auto. Grouped. For 1999, the mean values are 40200 miles/vehicle for Auto. Grouped versus 24500 miles/vehicle for not Auto. Grouped. For 2000, the mean values are 38900 miles/vehicle for Auto. Grouped versus 23500 miles/vehicle for not Auto. Grouped. Finally, for 2002, the mean values are 38100 miles/vehicle for Auto. Grouped versus 31100 miles/vehicle for not Auto. Grouped. The results for 1998 and 1999 are consistent with our previous study. We found no significant terms in the previous study's 1997 data. These results confirm that the use of CAD systems for route creation is beneficial.

The second most consistent relationship to PassMil/Veh is that of \%No-shows. This relationship appears in 1999-2002. The sense of the relationship is positive. Agencies with relatively high no-show rates have a greater PassMil/Veh value than agencies with relatively low no-show rates. For the 1999 data, the difference between an agency with $2 \%$ no-shows and an agency with $6 \%$ no-shows is 6700 miles/vehicle. For 2000, the difference between $2 \%$ no-shows and $6 \%$ no-shows is 18800 miles/vehicle. For 2001, the difference is 10400 miles/vehicle; and, for 2002, the difference is 5800 miles/vehicle. We interpret the seemingly beneficial impact of no-shows on this performance measure to be a result of the additional mileage that a would-be ridesharing passenger travels when the vehicle attempts to service a no-show request. It is an imperfection in 
the formulation of the productivity measure that produces this regression result. Agencies should not attempt to increase their no-show rates.

In 1998, 1999, 2001, and 2002 relationships to Complaints, Productivity, and Other are observed. These variables all indicate the use of financial penalty clauses in contracts with service providers. In each case, the sense of the relationship is positive. Agencies that use the penalty clauses have a higher PassMil/Veh value than those that do not. For the 1998 data, agencies that used penalties linked to Complaints had a mean PassMil/Veh value of 47000 miles/vehicle, while agencies that did not use penalties linked to complaints had a mean of 34000 miles/vehicle. In the same year, agencies that used penalties linked to Productivity had a mean of 47400 miles/vehicle versus 33900 for those who did not. Also, agencies that used penalties linked to Other measures had a mean of 44100 miles/vehicle versus 34000 miles/vehicle for those who did not. For 1999 and penalties linked to Other, the means are 43500 miles/vehicle versus 32500 miles/vehicle. For 2001 and penalties linked to Productivity, the means are 50300 miles/vehicle versus 32800 miles/vehicle. Finally, for 2002 and penalties linked to Other, the means are 43900 miles/vehicle versus 33700 miles/vehicle.

The results for 1998 and 1999 that indicate a beneficial impact from the use of financial penalty clauses in contracts with service providers are in conflict with the results of our previous study. The previous study showed no significant impact of financial penalties in 1998, and showed the combination of financial penalties and incentives to be detrimental to productivity in 1999. We can offer no interpretation for this seemingly beneficial impact of financial penalties. We do note that there are only 19 agencies in common between the responders to our previous survey and this current survey. There may be an as yet uninvestigated variable that accounts for the superior productivity of the agencies in the current survey group who use financial penalties. We also note that when the 1999 data for the two survey groups are combined, the financial penalties variable becomes insignificant. This observation further supports the hypothesis of stratification between the two survey groups according to an unidentified variable.

For the 1997 data, there are two relationships that have not yet been discussed. There is a positive relationship between PassMil/Veh and \%Cancelled. Agencies with relatively high cancellation rates have a greater PassMil/Veh value than agencies with relatively low cancellation rates. The difference between an agency with $6 \%$ cancellations and an agency with $15 \%$ 
cancellations is 6500 miles/vehicle. We believe that this impact may be related to the no-shows relationship described above. There is also a negative relationship between PassMil/Veh and Zones. Agencies that use zones have a mean PassMil/Veh value of 30600 miles/vehicle, while agencies that do not use zones have a mean of 36300 miles/vehicle. The use of zones is unproductive because it creates situations in which vehicles travel into an area where they are not allowed to make a pick-up and must deadhead back into their assigned zone.

For the 2001 data, there are also two additional relationships to discuss. There is a negative relationship between PassMil/Veh and Manual Revised. Agencies that revise routes manually on the day of use have a mean PassMil/Veh value of 35300 miles/vehicle, while agencies that do not revise manually have a mean of 57400 miles/vehicle. Manual revisions to vehicle routes during the day of use are likely to be unproductive because it is difficult for humans to correctly evaluate system-wide impacts quickly without computational aids. There is a negative relationship with Service Mileage. Agencies that pay contracted service providers on a mileage basis have a mean PassMil/Veh value of 36900 miles/vehicle, while agencies that do not pay contractors on a mileage basis have a mean of 37900 miles/vehicle. We interpret this impact as being the result of contractors who are paid on a mileage basis tending to drive more unloaded miles than necessary in order to increase charges to agencies.

The R-sq(adj) values for the 1998 and 1999 analyses in our previous study were 7\% and 15\% respectively. (No significant terms for the previous study's 1997 data corresponds to 0\% R-sq(adj).) The R-sq(adj) metric indicates the percentage of the observed variance in the performance measure that is attributable to the significant variables. The analysis results for the current study show that we have been able to identify variables that account for a greater portion of the observed performance variance than previously was the case.

The next analysis was for relationships to the Trip/Veh productivity measure. The scaling for the 2002 data is shown in Equation 3. The Box-Cox power transformation exponent was selected to be $\lambda=0.5$ for all years of NTD data. Tables 12 and 13 show all of the terms that were found to be significant at the $4 \%$ level.

$$
\text { ScaledLoading }=\frac{\text { Trip/Veh }-4800.9}{2267.4}
$$

The most consistent relationship to Trips/Veh is that with Manual Revised. This relationship 
Table 12: Passenger Trips per Vehicle Regression Results

\begin{tabular}{l|rr|rr|rr}
$y:(\text { ScaledLoading }+3)^{0.5}$ \\
\hline & \multicolumn{2}{|c}{1997} & & \multicolumn{3}{c}{1998} \\
Term & Coeff. Est. & p-value & Coeff. Est. & p-value & Coeff. Est. & p-value \\
\hline Manual Revised & -0.32 & 0.000 & -0.21 & 0.001 & - & - \\
Auto. Grouped & - & - & - & - & 0.26 & 0.001 \\
Complaints & 0.16 & 0.025 & - & - & - & - \\
Productivity & - & - & 0.14 & 0.011 & - & - \\
Ridesharing & - & - & 0.09 & 0.035 & - & - \\
Same Day & - & - & - & - & 0.37 & 0.000 \\
\%No-shows & - & - & - & - & 4.35 & 0.000 \\
Longest Notice & - & - & - & - & -0.02 & 0.003 \\
Zones & - & - & - & - & -0.23 & 0.006 \\
& & & & & $58 \%$ & \\
R-sq(adj) & $30 \%$ & & $30 \%$ & & $58 \%$ \\
\hline
\end{tabular}

is observed in all years except 1999. The sense of the relationship is negative. Agencies that manually revise routes on the day of use have a smaller Trips/Veh value than those that do not. For the 1997 data, agencies that Manual Revised had a mean Trip/Veh value of 4510 trips/vehicle, while agencies that did not had a mean of 6230 trips/vehicle. For 1998, the means are 4400 trips/vehicle versus 5880 trips/vehicle. For 2000, the means are 4070 trips/vehicle versus 6320 trips/vehicle. For 2001, the means are 4350 trips/vehicle versus 6520 trips/vehicle. Finally, for 2002 , the means are 4320 trips/vehicle versus 5510 trips/vehicle. As above, we interpret these results as an indication of the difficulty involved in manually evaluating the impact of route revisions.

In 1997, 1998, 2000, 2001, and 2002 relationships to Complaints, Productivity, and Other are

Table 13: Passenger Trips per Vehicle Regression Results

\begin{tabular}{l|rr|rr|rr}
$y:(\text { ScaledLoading }+3)^{0.5}$ & \multicolumn{2}{c}{2001} & \multicolumn{2}{c}{2002} \\
& \multicolumn{2}{|c}{2000} & & \\
Term & Coeff. Est. & p-value & Coeff. Est. & p-value & Coeff. Est. & p-value \\
\hline Manual Revised & -0.28 & 0.000 & -0.48 & 0.001 & -0.29 & 0.026 \\
Auto. Grouped & 0.20 & 0.003 & - & - & - & - \\
Productivity & 0.21 & 0.000 & 0.28 & 0.014 & - & - \\
Other & - & - & - & - & 0.23 & 0.002 \\
& & & $36 \%$ & & $20 \%$ \\
R-sq(adj) & $49 \%$ & & &
\end{tabular}


observed. These are all indicators of the use of financial penalty clauses in contracts with service providers. In each case, the relationship is positive. Agencies that use the penalty clauses have a higher Trip/Veh value than those that do not. For the 1997 data, agencies that used penalties linked to Complaints had a mean Trip/Veh value of 5660 trips/vehicle, while agencies that did not use penalties linked to complaints had a mean of 4390 trips/vehicle. For 1998, agencies using penalties linked to Productivity had a mean of 5400 trips/vehicle and agencies that did not had a mean of 4420 trips/vehicle. For 2000 and Productivity, the means are 5800 trips/vehicle and 3770 trips/vehicle. For 2001 and Productivity, the means are 5770 trips/vehicle and 4100 trips/vehicle. For 2002 and penalties linked to Other measures, the means are 5100 trips/vehicle and 4080 trips/vehicle. Our previous study revealed no significant impact of financial penalties on Trip/Veh in 1997-1999. Again, we interpret this result as an unexplained difference between the survey groups.

In 1999 and 2000 there are relationships to Auto. Grouped. This variable indicates the use of CAD software to group service requests into routes. In both years the relationship is positive. In 1999, agencies that used automatic grouping of requests had a mean of 4800 trips/vehicle and agencies that did not had a mean of 3650 trips/vehicle. In 2000, agencies that used automatic grouping of requests had a mean of 5100 trips/vehicle and agencies that did not had a mean of 4080 trips/vehicle. As above, use of CAD systems to automatically create vehicle routes is demonstrating productivity benefits.

In 1998, there is one other relationship that remains to be discussed. The Ridesharing indicator has a positive relationship to Trips/Veh. For agencies that use ridesharing, the mean is 4650 trips/vehicle. Agencies that do not use ridesharing have a mean of 4460 trips/vehicle. While this relationship is statistically significant, the practical importance of the impact is small.

In 1999, there are four relationships remaining to be discussed. Agencies that accept sameday requests have a mean of 5270 trips/vehicle, while agencies that do not have a mean of 4010 trips/vehicle. Same-day requests are beneficial because they allow agencies to fill gaps in routes that are created by no-shows and cancellations. Agencies that have a relatively high no-show rate have a greater Trips/Veh value than agencies that have a relatively low no-show rate. The difference between agencies with $2 \%$ no-shows and 6\% no-shows is 940 trips/vehicle. We hypothesize that no-shows appear beneficial here because the service request is still tallied as an unlinked 
trip, and the vehicle is freed early for other pick-ups. Agencies that allow a relatively long notice for requested travel have a smaller Trip/Veh value than agencies that only allow relatively short notice for advanced reservations. The difference between agencies that allow 14 days notice and those that allow only 6 days notice is 680 trips/vehicle. Allowing extended notice for advanced reservations may appear detrimental to productivity because these requests are more likely to produce a change of request. Finally, agencies that divide their service area into zones have a mean of 4420 trips/vehicle, while agencies that do not use zones have a mean of 4690 trips/vehicle. As above, the use of zones creates deadhead segments in the vehicle route and thereby reduces the number of requests serviced.

The $\mathrm{R}$-sq(adj) values for the 1997-1999 analyses in our previous study were 8\%, 11\%, and $13 \%$ respectively. As above, the analysis results for the current study show that we have been able to identify variables that account for a greater portion of the observed performance variance than previously was the case.

Results of analyses for relationships to the $A O C$ measure are shown in Tables 14 and 15. The $A O C$ measure is defined in Equation 1. A Box-Cox power transformation exponent of $\lambda=-0.5$ was selected for all years of NTD data. The tables show all terms found significant at the $4 \%$ level.

For the 1998 data, there is one relationship observed between $A O C$ and the use of Financial Incentives. The sense of the relationship is positive, i.e. agencies that use financial incentive clauses in contracts with service providers have a greater mean $A O C$ value than agencies that do not use incentives. The mean $A O C$ value for responding agencies that use incentives translates to a mean $O p E x p /$ Trip value of $\$ 26.50 /$ trip, and a mean OpExp/Pass Mil value of $\$ 3.80 /$ mile. The mean $A O C$ value for agencies that do not use incentives translates to a mean $O p E x p /$ Trip value of $\$ 19.00 /$ trip, and a mean OpExp/PassMil value of $\$ 2.65 /$ mile. We hypothesize that the addition of financial incentive clauses to contracts that already include financial penalties produces greater costs because contractors adjust their base rates to cover any losses from penalties and then expand their revenues by earning incentives.

For the 1999 data, there are two relationships to discuss. There is a positive relationship between $A O C$ and Service Hours. Agencies that pay contracted service providers on an hourly basis have a mean $A O C$ value that translates to a mean $O p E x p /$ Trip value of $\$ 24.25 /$ trip, and a 
Table 14: Average Operating Cost Regression Results

\begin{tabular}{|c|c|c|c|c|c|c|}
\hline \multirow[b]{2}{*}{ Term } & \multicolumn{2}{|c|}{1997} & \multicolumn{2}{|c|}{1998} & \multicolumn{2}{|c|}{1999} \\
\hline & Coeff. Est. & $\mathrm{p}$-value & Coeff. Est & $\mathrm{p}$-value & Coeff. Est. & $\mathrm{p}$-value \\
\hline Financial Incentives & - & - & $-0.0^{\prime}$ & 0.005 & - & - \\
\hline Service Hours & - & - & - & - & -0.08 & 0.000 \\
\hline Productivity & - & - & - & - & 0.06 & 0.022 \\
\hline $\mathrm{R}-\mathrm{sq}(\operatorname{adj})$ & & & $13 \%$ & & $22 \%$ & \\
\hline
\end{tabular}

mean $O p E x p / P a s s M i l$ value of $\$ 3.10 /$ mile. Agencies that do not pay contractors on an hourly basis have a mean $A O C$ value that translates to a mean $O p E x p /$ Trip value of $\$ 16.10 /$ trip, and a mean OpExp/PassMil value of $\$ 2.05 /$ mile. We interpret paying contractors on an hourly basis to be detrimental because drivers are paid for idle time. There is a negative relationship between $A O C$ and Productivity. Agencies that use financial penalty clauses linked to productivity have a lower mean $A O C$ value than those that do not. The mean $A O C$ for agencies that use productivity penalties translates to a mean OpExp/Trip value of $\$ 18.50 /$ trip, and a mean OpExp/PassMil value of $\$ 2.35 /$ mile. The mean $A O C$ for agencies that do not use productivity penalties translates to a mean $O p E x p /$ Trip value of $\$ 20.60 /$ trip, and a mean OpExp/Pass Mil value of $\$ 2.65 /$ mile. Our previous study found the use of financial penalties to produce increased costs in the 1999 data. This contradictory result may be the complementary cost benefit to the productivity impacts noted above, and therefore remains as an unexplained difference between the survey groups.

For the 2000 data, there is a negative relationship between $A O C$ and the practice of allowing requests for travel Outside the boundaries of the local fixed-route bus service. The mean $A O C$ for agencies that do service such requests translates to a mean OpExp/Trip value of $\$ 17.60 /$ trip, and a mean $O p E x p / P a s s M i l$ value of $\$ 2.15 /$ mile. The mean $A O C$ for agencies that do not accept

Table 15: Average Operating Cost Regression Results

\begin{tabular}{l|rr|rr|rr}
$y:(A O C+3)^{-0.5}$ & \multicolumn{2}{c}{2001} & \multicolumn{2}{c}{2002} \\
Term & Coeff. Est. & p-value & Coeff. Est. p-value & Coeff. Est. & p-value \\
\hline Outside & 0.04 & 0.031 & - & - & - & - \\
& & & & & \\
R-sq(adj) & $8 \%$ & & & & \\
\hline
\end{tabular}


request for travel outside the fixed-route bus boundaries translates to a mean OpExp/Trip value of $\$ 22.75 /$ trip, and a mean OpExp/PassMil value of $\$ 2.90 /$ mile. Since agencies are not required to accept requests for travel outside the boundaries of the local fixed-route bus service area, we assume that agencies choose to do so in order to achieve cost recovery.

The R-sq(adj) values for the 1998 and 1999 analyses in our previous study were 7\% and 4\% respectively. No significant terms were found for the previous study's 1997 data. The analysis results for the current study indicate that while there has been some improvement in accounting for the observed performance variance, we have not been able to identify as many important variables related to operating costs as we have found for productivity.

The analyses above compare the average performance of several agencies that have a given characteristic against the average performance of several other agencies that do not have the characteristic. It is possible that the differences in performance from agency-to-agency obscure or enhance the observed impacts. A before vs. after analysis for individual agencies would eliminate such agency-to-agency differences.

A before vs. after (paired comparison) analysis was performed for agencies that implemented any of the management practices shown in Table 3 or advanced technologies shown in Table 5 during 1998-2001. Each of the four performance measures (OpExp/Trip, OpExp/PassMil, PassMil/Veh, and Trip/Veh) was investigated separately. As above, performance in the reported year of implementation was ignored because it could not be attributed to either the before or after condition. The difference in performance between the year following implementation and the year preceeding implementation was calculated as the impact of the technology/practice. The average of the differences was then evaluated for statistical significance. None of the averages demonstrated significance at the $5 \%$ level. This is most likely due to the large amount of variablility in year-to-year results for individual agencies caused by a variety of as yet uninvestigated factors.

\section{Conclusions}

We have conducted a survey of transit agencies providing DRT service in medium sized and large urban centers throughout the United States. The survey has provided information regarding 
the implementation of advanced technologies and management practices for 67 agencies that responded. We have evaluated the impact of 28 operations variables on productivity and operating cost measures derived from information available in the 1997-2002 NTD.

Our analysis indicates that use of a Paratransit CAD system to group service requests into vehicle routes provides a productivity benefit of approximately 12000 passenger miles per vehicle, and 1100 trips per vehicle, annually. However, there is no corresponding cost impact. These results suggest that policy makers should continue to implement Paratransit CAD systems, but should also monitor cost impacts that offset the expected benefits from productivity improvement.

The practice of manually revising routes during the time of service produces a detrimental impact on productivity of approximately 1800 trips per vehicle annually. Policy makers should insist on some form of computational assistance for dispatchers, so that system-wide impacts of route revisions can be evaluated correctly in real time.

No-shows are identified as having a beneficial impact on productivity of approximately 10500 passenger miles per vehicle annually. This is a misleading result that is produced by a deficiency in the PassMil/Veh performance measure. Agencies should not attempt to increase their noshow rates. There is a need to identify more reliable measures of productivity that can be readily estimated.

The use of financial penalties was found to have benefical impacts on productivity and operating cost. This result is in conflict with the results of our previous study. We note that there are few agencies in common between the responders to the two surveys and attribute this apparent flip-flop in results to an as yet unidentified distinction between the two survey groups.

The portion of productivity performance variability explained by surveyed variables has increased substantially from the $10 \%$ level of the previous study. However, we stand at only about $40 \%$ of the productivity variability explained. The search to identify important variables related to operating cost has been less successful. Only about $10 \%$ of operating cost variability is explained, compared to about $5 \%$ previously. There is a need for further research to identify characteristics that determine performance. The recently announced request for proposals to the Transit Cooperative Research Program Project B-31, FY 2005, "Guidebook for Measuring, Assessing, and Improving Performance of Demand-Response Transportation", calls for research to identify both reliable metrics of performance and factors that affect performance of DRT systems. 


\section{Acknowledgement}

Funding for this project was provided by Partners for Advanced Transit and Highways (PATH) under a grant from Caltrans.

\section{References}

[1] Chira-Chavala, R., C. Venter. 1997. Cost and Productivity Impacts of a Smart Paratransit System, Transportation Research Record, No. 1571, 81-87.

[2] Dessouky, M., K. Palmer, T. Abdelmaguid. 2003. Benchmarking Best Practices of Demand Responsive Transit Systems, UCB-ITS-PRR-2003-1, California PATH Research Report, Richmond, California.

[3] Draper, N., H. Smith. 1981. Applied Regression Analysis, second edition, John Wiley \& Sons, New York.

[4] Federal Transit Administration. 2003. National Transit Summaries and Trends, available at www.ntdprogram.com

[5] Gilbert, G., T. Cook. 1999. The Private-for-hire Vehicle (PHV) Industry and Its Contracts with Public Transit Operators, Proceedings of the 1999 Transportation Research Board Conference, Washington, D.C.

[6] Goeddel, D. 1996. Benefits Assessment of Advanced Public Transportation Systems, U.S. Department of Transportation, Washington, D.C.

[7] Higgins, L., J.B. Laughlin, K. Turnbull. 2000. Automatic Vehicle Location and Advanced Paratransit Scheduling at Houston METROLift, Proceedings of the 2000 Transportation Research Board Conference, Washington, D.C.

[8] John A. Volpe National Transportation Systems Center. 2002. Advanced Public Transportation Systems Deployment in the United States, Year 2000, Update, National Technical Information Service order number PB2002-106770. 
[9] Johnson, R.A., D.W. Wichern. 1992. Applied Multivariate Statistical Analysis, third edition, Prentice-Hall, Inc., Upper Saddle River, NJ.

[10] Massart, D.L., L. Kaufman. 1983. The Interpretation of Analytical Chemical Data by the Use of Cluster Analysis, John Wiley \& Sons, New York.

[11] Myers, R.H., D.C. Montgomery. 2002. Response Surface Methodology, second edition, John Wiley \& Sons, New York.

[12] Palmer, K., M. Dessouky, T. Abdelmaguid. 2004. Impacts of Management Practices and Advanced Technologies on Demand Responsive Transit Systems, Transportation Research, Part A: Policy and Practice, 38: 495-509.

[13] Rufolo, A.M., J.G. Strathman, Z. Peng. 1997. Cost Effectiveness of Demand Responsive Versus Fixed Route Transit Service: Portland, Oregon Case Study, Transportation Research Record, No. 1571, 1-10.

[14] SAS Institute. 1988. SAS/STAT User's Guide, Release 6.03 edition, SAS Institute, Inc., Cary, NC.

[15] Simon, R.M. 1998. Paratransit Contracting and Service Delivery Methods, Transit Cooperative Research Program Synthesis \#31, Transportation Research Board, Washington, D.C.

[16] Stone, J.R., A.M. Nalevanko, G. Gilbert. 1994. Computer Dispatch and Scheduling for Paratransit: An Application of Advanced Public Transportation Systems, Transportation Quarterly, 48(2): 173-184.

[17] Wallace, R.R. 1997. Paratransit Customer: Modeling Elements of Satisfaction with Service, Transportation Research Record, No. 1571, 59-66. 
A Surveyed Agencies 

Surveyed Agencies

\begin{tabular}{|c|c|c|c|}
\hline TRS ID & Agency Name & City & State \\
\hline 0001 & $\begin{array}{l}\text { King County Department of Transportation - } \\
\text { Metro Transit Division }\end{array}$ & Seattle & WA \\
\hline 0002 & Spokane Transit Authority & Spokane & WA \\
\hline 0003 & Pierce County Transportation Benefit Area Authority & Tacoma & WA \\
\hline 0007 & Lane Transit District & Eugene & OR \\
\hline 0008 & Tri-County Metropolitan Transportation District of Oregon & Portland & OR \\
\hline 0012 & Municipality of Anchorage - Public Transportation Department & Anchorage & AK \\
\hline 0020 & Kitsap Transit & Bremerton & WA \\
\hline 0024 & Clark County Public Transportation Benefit Area Authority & Vancouver & WA \\
\hline 0025 & Salem Area Mass Transit District & Salem & OR \\
\hline 0029 & Snohomish County Transportation Benefit Area Corporation & Everett & WA \\
\hline 0033 & Senior Services of Snohomish County & Mukilteo & WA \\
\hline 1001 & Rhode Island Public Transit Authority & Providence & RI \\
\hline 1003 & Massachusetts Bay Transportation Authority & Boston & MA \\
\hline 1004 & Brockton Area Transit Authority & Brockton & MA \\
\hline 1005 & Lowell Regional Transit Authority & Lowell & MA \\
\hline 1008 & Pioneer Valley Transit Authority & Springfield & MA \\
\hline 1017 & Greater Hartford Transit District & Hartford & $\mathrm{CT}$ \\
\hline 1040 & Southeast Area Transit & Preston & $\mathrm{CT}$ \\
\hline 1049 & The Greater New Haven Transit District & Hamden & CT \\
\hline 1050 & Greater Bridgeport Transit Authority & Bridgeport & $\mathrm{CT}$ \\
\hline 1069 & The Regional Transportation Program, Inc. & Portland & $\mathrm{ME}$ \\
\hline 1102 & Connecticut Department of Transportation & Newington & $\mathrm{CT}$ \\
\hline 1105 & Cape Cod Regional Transit Authority & Hyannis & MA \\
\hline 2002 & Capital District Transportation Authority & Albany & NY \\
\hline 2004 & Niagara Frontier Transportation Authority & Buffalo & NY \\
\hline 2007 & $\begin{array}{l}\text { Metropolitan Suburban Bus Authority, } \\
\text { dba: MTA Long Island Bus }\end{array}$ & Garden City & NY \\
\hline 2008 & MTA New York City Transit & Brooklyn & NY \\
\hline 2018 & Central New York Regional Transportation Authority & Syracuse & NY \\
\hline 2072 & $\begin{array}{l}\text { Suffolk County Department of Public Works - } \\
\text { Transportation Division }\end{array}$ & Yaphank & NY \\
\hline 2076 & Westchester County Department of Transportation & Mount Vernon & NY \\
\hline 2080 & New Jersey Transit Corporation & Newark & NJ \\
\hline 2086 & $\begin{array}{l}\text { Transportation Resources Intra-County for } \\
\text { Physically Handicapped and Senior Citizens }\end{array}$ & Pomona & NY \\
\hline 2113 & Regional Transit Services, Inc. and Lift Line, Inc. & Rochester & NY \\
\hline 2148 & Newburgh Beacon Bus Corporation & New Windsor & NY \\
\hline 2159 & Atlantic Paratrans, Inc. & Staten Island & NY \\
\hline 2173 & American Transit, Inc. & Yonkers & NY \\
\hline 3001 & Kanawha Valley Regional Transportation Authority & Charleston & WV \\
\hline 3006 & Greater Richmond Transit Company & Richmond & VA \\
\hline 3010 & Lehigh and Northampton Transportation Authority & Allentown & PA \\
\hline
\end{tabular}


Surveyed Agencies (cont.)

\begin{tabular}{|c|c|c|c|}
\hline TRS ID & Agency Name & City & State \\
\hline 3014 & Capital Area Transit & Harrisburg & $\overline{\mathrm{PA}}$ \\
\hline 3015 & Luzerne County Transportation Authority & Kingston & $\mathrm{PA}$ \\
\hline 3018 & Red Rose Transit Authority & Lancaster & PA \\
\hline 3019 & Southeastern Pennsylvania Transportation Authority & Philadelphia & PA \\
\hline 3022 & Port Authority of Allegheny County & Pittsburgh & PA \\
\hline 3023 & Beaver County Transit Authority & Rochester & PA \\
\hline 3024 & Berks Area Reading Transportation Authority & Reading & PA \\
\hline 3025 & County of Lackawanna Transit System & Scranton & $\mathrm{PA}$ \\
\hline 3030 & Washington Metropolitan Area Transit Authority & Washington & $\mathrm{DC}$ \\
\hline 3034 & Maryland Transit Administration & Baltimore & MD \\
\hline 3044 & Westmoreland County Transit Authority & Greensburg & PA \\
\hline 3051 & Ride-On Montgomery County Transit & Rockville & MD \\
\hline 3074 & Harford County Transportation Services & Abingdon & MD \\
\hline 3075 & Delaware Transit Corporation & Dover & DE \\
\hline 3083 & $\begin{array}{l}\text { Transportation District Commission of Hampton Roads, } \\
\text { dba: Hampton Roads Transit }\end{array}$ & Hampton & VA \\
\hline 4001 & Chattanooga Area Regional Transportation Authority & Chattanooga & TN \\
\hline 4003 & Memphis Area Transit Authority & Memphis & TN \\
\hline 4004 & Metropolitan Transit Authority & Nashville & $\mathrm{TN}$ \\
\hline 4007 & Capital Area Transit & Raleigh & $\mathrm{NC}$ \\
\hline 4008 & Charlotte Area Transit System & Charlotte & $\mathrm{NC}$ \\
\hline 4012 & $\begin{array}{l}\text { Winston-Salem Transit Authority - } \\
\text { Trans-Aid of Forsyth County }\end{array}$ & Winston-Salem & $\mathrm{NC}$ \\
\hline 4018 & Transit Authority of River City & Louisville & KY \\
\hline 4019 & Transit Authority of Northern Kentucky & Fort Wright & $\mathrm{KY}$ \\
\hline 4022 & Metropolitan Atlanta Rapid Transit Authority & Atlanta & GA \\
\hline 4023 & Augusta Richmond County Transit Department & Augusta & GA \\
\hline 4024 & Department of Transportation & Columbus & GA \\
\hline 4025 & Chatham Area Transit Authority & Savannah & GA \\
\hline 4026 & Manatee County Area Transit & Bradenton & FL \\
\hline 4027 & Pinellas Suncoast Transit Authority & Clearwater & FL \\
\hline 4028 & Lee County Transit & Ft. Myers & FL \\
\hline 4029 & Broward County Mass Transit Division & Pompano Beach & FL \\
\hline 4032 & County of Volusia, dba: VOTRAN & South Daytona & FL \\
\hline 4034 & Miami-Dade Transit & Miami & FL \\
\hline 4035 & Central Florida Regional Transportation Authority & Orlando & FL \\
\hline 4037 & Palm Tran, Inc. & West Palm Beach & FL \\
\hline 4038 & Escambia County Area Transit & Pensacola & FL \\
\hline 4040 & Jacksonville Transportation Authority & Jacksonville & FL \\
\hline 4041 & Hillsborough Area Regional Transit Authority & Tampa & FL \\
\hline 4042 & Birmingham-Jefferson County Transit Authority & Birmingham & $\mathrm{AL}$ \\
\hline
\end{tabular}


Surveyed Agencies (cont.)

\begin{tabular}{|c|c|c|c|}
\hline TRS ID & Agency Name & City & State \\
\hline 4043 & Metro Transit & Mobile & $\mathrm{AL}$ \\
\hline 4046 & Sarasota County Area Transit & Sarasota & FL \\
\hline 4053 & Greenville Transit Authority & Greenville & $\mathrm{SC}$ \\
\hline 4056 & Pee Dee Regional Transportation Authority & Florence & $\mathrm{SC}$ \\
\hline 4063 & Space Coast Area Transit & Cocoa & FL \\
\hline 4071 & City of Huntsville, Alabama - Public Transportation Division & Huntsville & $\mathrm{AL}$ \\
\hline 4074 & Pasco County Public Transportation & Port Richey & FL \\
\hline 4078 & Cobb County Department of Transportation Authority & Marietta & GA \\
\hline 4086 & Metropolitan Bus Authority & San Juan & PR \\
\hline 4097 & Council on Aging of St. Lucie, Inc. & Fort Pierce & FL \\
\hline 4100 & Santee Wateree Regional Transportation Authority & Sumter & $\mathrm{SC}$ \\
\hline 4110 & Charleston Area Regional Transportation Authority & Charleston & $\mathrm{SC}$ \\
\hline 4113 & Council on Aging of Martin County, Inc. & Stuart & FL \\
\hline 5005 & Madison Metro Transit System & Madison & WI \\
\hline 5008 & Milwaukee County Transit System & Milwaukee & WI \\
\hline 5010 & Metro Regional Transit Authority & Akron & $\mathrm{OH}$ \\
\hline 5011 & Stark Area Regional Transit Authority & Canton & $\mathrm{OH}$ \\
\hline 5012 & Southwest Ohio Regional Transit Authority & Cincinnati & $\mathrm{OH}$ \\
\hline 5015 & The Greater Cleveland Regional Transit Authority & Cleveland & $\mathrm{OH}$ \\
\hline 5016 & Central Ohio Transit Authority & Columbus & $\mathrm{OH}$ \\
\hline 5017 & Greater Dayton Regional Transit Authority & Dayton & $\mathrm{OH}$ \\
\hline 5022 & Toledo Area Regional Transit Authority & Toledo & $\mathrm{OH}$ \\
\hline 5024 & Western Reserve Transit Authority & Youngstown & $\mathrm{OH}$ \\
\hline 5032 & Mass Transportation Authority & Flint & MI \\
\hline 5033 & Interurban Transit Partnership & Grand Rapids & MI \\
\hline 5036 & Capital Area Transportation Authority & Lansing & MI \\
\hline 5038 & Niles Dial-A-Ride & Niles & MI \\
\hline 5048 & LCEOC, Inc. & Hammond & IN \\
\hline 5050 & Indianapolis \& Marion County Public Transportation & Indianapolis & IN \\
\hline 5058 & Rockford Mass Transit District & Rockford & IL \\
\hline 5066 & Chicago Transit Authority & Chicago & IL \\
\hline 5094 & Waukesha County Transit System & Waukesha & WI \\
\hline 5113 & Pace — Suburban Bus Division & Arlington Heights & IL \\
\hline 5117 & LakeTran & Grand River & $\mathrm{OH}$ \\
\hline 5119 & City of Detroit Department of Transportation & Detroit & MI \\
\hline 5146 & Madison County Transit District & Granite City & IL \\
\hline 5154 & Metropolitan Council & St. Paul & $\mathrm{MN}$ \\
\hline 5155 & Metro Mobility & St. Paul & $\mathrm{MN}$ \\
\hline 5157 & Butler County Regional Transit Authority & Hamilton & $\mathrm{OH}$ \\
\hline 6006 & Mass Transit Department - City of El Paso & El Paso & TX \\
\hline
\end{tabular}


Surveyed Agencies (cont.)

\begin{tabular}{|c|c|c|c|}
\hline TRS ID & Agency Name & City & State \\
\hline 6007 & Fort Worth Transportation Authority & Fort Worth & TX \\
\hline 6008 & Metropolitan Transit Authority of Harris County, Texas & Houston & TX \\
\hline 6011 & VIA Metropolitan Transit & San Antonio & TX \\
\hline 6017 & Central Oklahoma Transportation and Parking Authority & Oklahoma City & OK \\
\hline 6018 & Metropolitan Tulsa Transit Authority & Tulsa & OK \\
\hline 6019 & Sun Tran of Albuquerque & Albuquerque & NM \\
\hline 6022 & Capital Transportation Corporation & Baton Rouge & LA \\
\hline 6024 & Shreveport Area Transit System & Shreveport & LA \\
\hline 6032 & New Orleans Regional Transit Authority & New Orleans & LA \\
\hline 6041 & Handitran Special Transit Division - City of Arlington & Arlington & TX \\
\hline 6048 & Capital Metropolitan Transportation Authority & Austin & TX \\
\hline 6051 & Corpus Christi Regional Transportation Authority & Corpus Christi & TX \\
\hline 6056 & Dallas Area Rapid Transit & Dallas & TX \\
\hline 6082 & The Gulf Coast Center & Galveston & TX \\
\hline 6087 & First Transit, Inc. & Houston & TX \\
\hline 6088 & Jefferson Parish Department of Transit Administration & Gretna & LA \\
\hline 6090 & Lower Rio Grande Valley Development Council & McAllen & TX \\
\hline 6091 & Hill Country Transit District & San Saba & TX \\
\hline 6092 & ATC / Vancom & Dallas & TX \\
\hline 7001 & StarTran & Lincoln & $\mathrm{NE}$ \\
\hline 7002 & Transit Authority of Omaha & Omaha & $\mathrm{NE}$ \\
\hline 7005 & Kansas City Area Transportation Authority & Kansas City & $\mathrm{MO}$ \\
\hline 7006 & Bi-State Development Agency & St. Louis & $\mathrm{MO}$ \\
\hline 7010 & Des Moines Metropolitan Transit Authority & Des Moines & IA \\
\hline 7015 & Wichita Transit & Wichita & KS \\
\hline 7035 & Johnson County Kansas, aka: Johnson County Transit & Olathe & KS \\
\hline 8001 & Utah Transit Authority & Salt Lake City & UT \\
\hline 8005 & Colorado Springs Transit System & Colorado Springs & $\mathrm{CO}$ \\
\hline 8006 & Denver Regional Transportation District & Denver & $\mathrm{CO}$ \\
\hline 8011 & Transfort & Fort Collins & $\mathrm{CO}$ \\
\hline 9001 & Regional Transportation Commission of Washoe County & Reno & NV \\
\hline 9002 & $\begin{array}{l}\text { City and County of Honolulu Department of } \\
\text { Transportation Services }\end{array}$ & Honolulu & HI \\
\hline 9003 & Bay Area Rapid Transit District & Oakland & $\mathrm{CA}$ \\
\hline 9006 & Santa Cruz Metropolitan Transit District & Santa Cruz & $\mathrm{CA}$ \\
\hline 9008 & Santa Monica’s Big Blue Bus & Santa Monica & $\mathrm{CA}$ \\
\hline 9009 & San Mateo County Transit District & San Carlos & $\mathrm{CA}$ \\
\hline 9010 & Torrance Transit System & Torrance & $\mathrm{CA}$ \\
\hline 9012 & San Joaquin Regional Transit District & Stockton & $\mathrm{CA}$ \\
\hline 9013 & Santa Clara Valley Transportation Authority & San Jose & $\mathrm{CA}$ \\
\hline 9014 & Alameda-Contra Costa Transit District & Oakland & $\mathrm{CA}$ \\
\hline
\end{tabular}


Surveyed Agencies (cont.)

\begin{tabular}{|c|c|c|c|}
\hline TRS ID & Agency Name & City & State \\
\hline 9015 & San Francisco Municipal Railway & San Francisco & $\mathrm{CA}$ \\
\hline 9016 & Golden Gate Bridge, Highway and Transportation District & San Francisco & $\mathrm{CA}$ \\
\hline 9019 & Sacramento Regional Transit District & Sacramento & $\mathrm{CA}$ \\
\hline 9022 & Norwalk Transit System & Norwalk & $\mathrm{CA}$ \\
\hline 9023 & Long Beach Transit & Long Beach & $\mathrm{CA}$ \\
\hline 9027 & Fresno Area Express & Fresno & $\mathrm{CA}$ \\
\hline 9028 & City of Vallejo Transportation Program & Vallejo & $\mathrm{CA}$ \\
\hline 9029 & Omnitrans & San Bernardino & $\mathrm{CA}$ \\
\hline 9030 & North San Diego County Transit District & Oceanside & $\mathrm{CA}$ \\
\hline 9031 & Riverside Transit Agency & Riverside & $\mathrm{CA}$ \\
\hline 9032 & City of Phoenix Public Transit Department & Phoenix & AZ \\
\hline 9033 & City of Tucson & Tucson & AZ \\
\hline 9034 & City of Glendale Transit & Glendale & AZ \\
\hline 9035 & South Coast Area Transit & Oxnard & $\mathrm{CA}$ \\
\hline 9036 & Orange County Transportation Authority & Orange & $\mathrm{CA}$ \\
\hline 9041 & Montebello Bus Lines & Montebello & $\mathrm{CA}$ \\
\hline 9042 & City of Gardena Transportation Department & Gardena & CA \\
\hline 9045 & Regional Transportation Commission of Southern Nevada & Las Vegas & NV \\
\hline 9062 & Monterey-Salinas Transit & Monterey & $\mathrm{CA}$ \\
\hline 9078 & Central Contra Costa Transit Authority & Concord & $\mathrm{CA}$ \\
\hline 9079 & SunLine Transit Agency & Thousand Palms & $\mathrm{CA}$ \\
\hline 9086 & City of Riverside Special Transportation & Riverside & CA \\
\hline 9089 & Sonoma County Transit & Santa Rosa & $\mathrm{CA}$ \\
\hline 9090 & Yolo County Transportation District & Woodland & CA \\
\hline 9121 & Antelope Valley Transit Authority & Lancaster & $\mathrm{CA}$ \\
\hline 9129 & City of Mesa & Mesa & AZ \\
\hline 9132 & Maricopa County Special Transportation Services & Phoenix & AZ \\
\hline 9147 & City of Los Angeles Department of Transportation & Los Angeles & $\mathrm{CA}$ \\
\hline 9157 & Access Services Incorporated & Los Angeles & $\mathrm{CA}$ \\
\hline 9162 & Eastern Contra Costa Transit Authority & Antioch & $\mathrm{CA}$ \\
\hline 9166 & Los Angeles County Metropolitan Transportation Authority & Los Angeles & $\mathrm{CA}$ \\
\hline 9170 & ATC / Vancom & Oakland & CA \\
\hline 9185 & San Diego Metropolitan Transit Development Board & San Diego & $\mathrm{CA}$ \\
\hline 9188 & County of San Diego Transit System & San Diego & $\mathrm{CA}$ \\
\hline
\end{tabular}





\section{B Survey Form}





\section{Demand Responsive Transit Service Survey}

NTD ID Number:

Agency Name:

\section{Operational Characteristics}

Is your service area divided into zones that limit where a particular provider may pick-up a customer? Yes $\quad$ No

If yes, how many distinct zones?

Is scheduling coordinated across the zones?

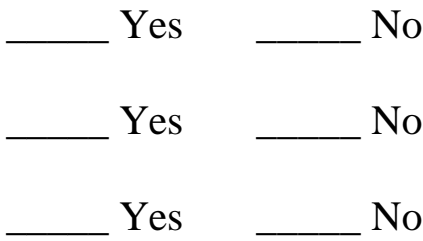

Do you accept advanced reservations?

If yes, what is the longest notice for which a customer may request a pick-up?

Do you handle same-day requests? Yes No

If yes, what is the shortest notice for which a customer may request a pick-up?

Does you accept requests for travel outside the boundaries of the local fixed-route bus service? Yes No

What percentage of service requests does your agency handle by directly operated vehicle?

On what basis are contracted providers paid?

Service requests Service hours Service mileage

Are drivers considered employees or independent contractors?

What percentage of your service requests do customers cancel after routes are planned?

What percentage of your service requests do customers fail to show for the pick-up?

How do you deal with reservations for return travel when the outbound reservation produces a customer no-show?

How are customers impacted when they produce no-shows? No impact Phone call Letter Other (please specify): 


\section{Management Practices}

For each practice in use, please indicate the year that the practice was first implemented. If the year is uncertain, please indicate an estimate with an asterisk, eg: 2001*

Financial penalties - charges to contractors, deducted from the base fee, contingent upon service performance results

Financial incentives - payments to contractors, in addition to the base fee, contingent upon service performance results

Ridesharing - a vehicle simultaneously serves trip requests from more than one customer by use of a carpooling strategy

Agency administration - the agency named on the survey performs the following functions: determines ADA eligibility, arranges for use of vehicles and services of drivers, monitors service performance, and distributes funds in payment for transportation

Contracted administration - the agency named on the survey contracts another organization(s) to perform the functions listed above

Consumer choice - customers are allowed a selection of providers (among the agency and its contractors) to service a trip request

\section{Implementation of Financial Penalties/Incentives}

What performance measures does your agency link to financial incentives?

On-time pick-ups Driver turnover
Productivity

Other (please specify):
Customer complaints

How often are incentives awarded?

What performance measures does your agency link to financial penalties?

On-time pick-ups

Driver turnover
Productivity

Other (please specify):
Customer complaints

How often are penalties assessed?

What are the limits of your on-time window?

Earliest arrival before requested pick-up:

Latest arrival after requested pick-up: 


\section{Advanced Technologies}

For each technology in use, please indicate the year that the technology was first implemented. If the year is uncertain, please indicate an estimate with an asterisk, eg: 2001*

Advanced communications - digital radio or wireless personal communication systems used to transmit voice and/or data between the vehicle and the dispatch center

Automated vehicle location - computer-based tracking system that includes a method of determining vehicle location (such as global positioning system, active signposts, ground-based radio) and a method of transmitting data from the vehicle to the dispatch center

Automated fare payment - a system that allows customers to use magnetic stripe cards, smart cards, credit cards, or debit cards for fare payment via in-vehicle readers, telephone, or the internet

Automated transit information - a computer-based system for disseminating real-time information (such as vehicle location or anticipated arrival times) to customers via kiosks, the internet, on-board voice annunciators, or interactive telephone systems

Paratransit CAD system - single software package, or integrated collection of software products, that provide Computer-Aided Dispatching capabilities such as scheduling, routing, and dispatching.

\section{Uses of Computer-Aided Dispatching}

How are service requests grouped into routes for each vehicle? Manually _ Automatically, by using a CAD software

If routes are created automatically, does dispatch staff revise the routes manually before use? Yes _ No

How are routes revised during the time of use?

$$
\text { Other (please specify): }
$$

Automatically, by using a CAD software

How long in advance are routes planned?

Over what period of time is a route planned to occur?
Full-day
Half-day

Other (please specify):

What is the amount of requests given to a driver at one time?

Full-day Half-day One-at-a-time

Other (please specify): 

C Responding Agencies 



\begin{tabular}{|c|c|c|c|}
\hline TRS ID & Agency Name & City & State \\
\hline 0008 & Tri-County Metropolitan Transportation District of Oregon & Portland & OR \\
\hline 0029 & Snohomish County Transportation Benefit Area Corporation & Everett & WA \\
\hline 1003 & Massachusetts Bay Transportation Authority & Boston & MA \\
\hline 1049 & The Greater New Haven Transit District & Hamden & $\mathrm{CT}$ \\
\hline 2004 & Niagara Frontier Transportation Authority & Buffalo & NY \\
\hline 2008 & MTA New York City Transit & Brooklyn & NY \\
\hline 2080 & New Jersey Transit Corporation & Newark & NJ \\
\hline 2086 & $\begin{array}{l}\text { Transportation Resources Intra-County for } \\
\text { Physically Handicapped and Senior Citizens }\end{array}$ & Pomona & NY \\
\hline 3018 & Red Rose Transit Authority & Lancaster & PA \\
\hline 3022 & Port Authority of Allegheny County & Pittsburgh & PA \\
\hline 3025 & County of Lackawanna Transit System & Scranton & PA \\
\hline 3030 & Washington Metropolitan Area Transit Authority & Washington & $\mathrm{DC}$ \\
\hline 3034 & Maryland Transit Administration & Baltimore & MD \\
\hline 3044 & Westmoreland County Transit Authority & Greensburg & PA \\
\hline 4001 & Chattanooga Area Regional Transportation Authority & Chattanooga & $\mathrm{TN}$ \\
\hline 4008 & Charlotte Area Transit System & Charlotte & $\mathrm{NC}$ \\
\hline 4012 & $\begin{array}{l}\text { Winston-Salem Transit Authority - } \\
\text { Trans-Aid of Forsyth County }\end{array}$ & Winston-Salem & $\mathrm{NC}$ \\
\hline 4019 & Transit Authority of Northern Kentucky & Fort Wright & KY \\
\hline 4022 & Metropolitan Atlanta Rapid Transit Authority & Atlanta & GA \\
\hline 4024 & Department of Transportation & Columbus & GA \\
\hline 4026 & Manatee County Area Transit & Bradenton & FL \\
\hline 4029 & Broward County Mass Transit Division & Pompano Beach & FL \\
\hline 4035 & Central Florida Regional Transportation Authority & Orlando & FL \\
\hline 4041 & Hillsborough Area Regional Transit Authority & Tampa & FL \\
\hline 4053 & Greenville Transit Authority & Greenville & $\mathrm{SC}$ \\
\hline 4074 & Pasco County Public Transportation & Port Richey & FL \\
\hline 5005 & Madison Metro Transit System & Madison & WI \\
\hline 5010 & Metro Regional Transit Authority & Akron & $\mathrm{OH}$ \\
\hline 5011 & Stark Area Regional Transit Authority & Canton & $\mathrm{OH}$ \\
\hline 5017 & Greater Dayton Regional Transit Authority & Dayton & $\mathrm{OH}$ \\
\hline 5032 & Mass Transportation Authority & Flint & MI \\
\hline 5050 & Indianapolis \& Marion County Public Transportation & Indianapolis & IN \\
\hline 5058 & Rockford Mass Transit District & Rockford & IL \\
\hline 5066 & Chicago Transit Authority & Chicago & IL \\
\hline 5117 & LakeTran & Grand River & $\mathrm{OH}$ \\
\hline 5119 & City of Detroit Department of Transportation & Detroit & MI \\
\hline 6008 & Metropolitan Transit Authority of Harris County, Texas & Houston & TX \\
\hline 6011 & VIA Metropolitan Transit & San Antonio & TX \\
\hline 6018 & Metropolitan Tulsa Transit Authority & Tulsa & $\mathrm{OK}$ \\
\hline
\end{tabular}


Responding Agencies (cont.)

\begin{tabular}{|c|c|c|c|}
\hline TRS ID & Agency Name & City & State \\
\hline 6024 & Shreveport Area Transit System & Shreveport & LA \\
\hline 6041 & Handitran Special Transit Division - City of Arlington & Arlington & TX \\
\hline 6056 & Dallas Area Rapid Transit & Dallas & TX \\
\hline 6082 & The Gulf Coast Center & Galveston & TX \\
\hline 7001 & StarTran & Lincoln & $\mathrm{NE}$ \\
\hline 7006 & Bi-State Development Agency & St. Louis & $\mathrm{MO}$ \\
\hline 7015 & Wichita Transit & Wichita & KS \\
\hline 7035 & Johnson County Kansas, aka: Johnson County Transit & Olathe & $\mathrm{KS}$ \\
\hline 8001 & Utah Transit Authority & Salt Lake City & UT \\
\hline 8006 & Denver Regional Transportation District & Denver & $\mathrm{CO}$ \\
\hline 8011 & Transfort & Fort Collins & $\mathrm{CO}$ \\
\hline 9001 & Regional Transportation Commission of Washoe County & Reno & NV \\
\hline 9002 & $\begin{array}{l}\text { City and County of Honolulu Department of } \\
\text { Transportation Services }\end{array}$ & Honolulu & HI \\
\hline 9008 & Santa Monica’s Big Blue Bus & Santa Monica & $\mathrm{CA}$ \\
\hline 9010 & Torrance Transit System & Torrance & $\mathrm{CA}$ \\
\hline 9028 & City of Vallejo Transportation Program & Vallejo & $\mathrm{CA}$ \\
\hline 9029 & Omnitrans & San Bernardino & $\mathrm{CA}$ \\
\hline 9030 & North San Diego County Transit District & Oceanside & $\mathrm{CA}$ \\
\hline 9032 & City of Phoenix Public Transit Department & Phoenix & $\mathrm{AZ}$ \\
\hline 9034 & City of Glendale Transit & Glendale & $\mathrm{AZ}$ \\
\hline 9036 & Orange County Transportation Authority & Orange & $\mathrm{CA}$ \\
\hline 9062 & Monterey-Salinas Transit & Monterey & $\mathrm{CA}$ \\
\hline 9078 & Central Contra Costa Transit Authority & Concord & $\mathrm{CA}$ \\
\hline 9089 & Sonoma County Transit & Santa Rosa & $\mathrm{CA}$ \\
\hline 9090 & Yolo County Transportation District & Woodland & $\mathrm{CA}$ \\
\hline 9121 & Antelope Valley Transit Authority & Lancaster & $\mathrm{CA}$ \\
\hline 9157 & Access Services Incorporated & Los Angeles & $\mathrm{CA}$ \\
\hline 9166 & Los Angeles County Metropolitan Transportation Authority & Los Angeles & $\mathrm{CA}$ \\
\hline 9185 & San Diego Metropolitan Transit Development Board & San Diego & $\mathrm{CA}$ \\
\hline
\end{tabular}


D Raw Survey Data 

Operational Characteristics, Part 1

\begin{tabular}{|c|c|c|c|c|c|c|}
\hline TRS ID & Zones & $\begin{array}{l}\text { Number } \\
\text { of Zones }\end{array}$ & $\begin{array}{l}\text { Coordinate } \\
\text { Zones }\end{array}$ & $\begin{array}{l}\text { Standing } \\
\text { Reserv. }\end{array}$ & $\begin{array}{l}\text { Advanced } \\
\text { Reserv. }\end{array}$ & $\begin{array}{l}\text { Longest } \\
\text { Notice }\end{array}$ \\
\hline 0008 & No & & Yes & Yes & Yes & 14 \\
\hline 0029 & No & & & Yes & Yes & 7 \\
\hline 1003 & Yes & 4 & Yes & Yes & Yes & 14 \\
\hline 1049 & No & & & Yes & Yes & 7 \\
\hline 2004 & Yes & 4 & Yes & No & Yes & 14 \\
\hline 2008 & Yes & 9 & Yes & Yes & Yes & $\begin{array}{l}\text { AAR customer 1-2; } \\
\text { subscription can } \\
\text { last for an } \\
\text { indeterminable } \\
\text { amount of } \\
\text { days/months }\end{array}$ \\
\hline 2080 & Yes & 5 & Yes & Yes & Yes & 14 \\
\hline 2086 & No & & Yes & Yes & Yes & 30 \\
\hline 3018 & Yes & 6 & Yes & Yes & Yes & 14 \\
\hline 3022 & Yes & 11 & No & Yes & Yes & Friday for Monday \\
\hline 3025 & No & $\mathrm{N} / \mathrm{A}$ & No & Yes & Yes & $\begin{array}{l}\text { Ongoing } \\
\text { appointments } \\
\text { are allowed }\end{array}$ \\
\hline 3030 & No & & Yes & Yes & Yes & 14 \\
\hline 3034 & No & & & Yes & Yes & 14 \\
\hline 3044 & Yes & 7 & No & Yes & Yes & 14 \\
\hline 4001 & No & & Yes & Yes & Yes & 14 \\
\hline 4008 & No & & & Yes & Yes & 5 \\
\hline 4012 & No & & $\mathrm{N} / \mathrm{A}$ & Yes & Yes & $\begin{array}{l}\text { same day if we } \\
\text { have the capacity } \\
\text { and time }\end{array}$ \\
\hline 4019 & No & & & Yes & Yes & 14 \\
\hline 4022 & No & & $\mathrm{N} / \mathrm{A}$ & Yes & Yes & 7 \\
\hline 4024 & No & & No & Yes & Yes & 14 \\
\hline 4026 & No & & Yes & Yes & Yes & 14 \\
\hline 4029 & No & & Yes & Yes & Yes & 4 \\
\hline 4035 & No & $\mathrm{N} / \mathrm{A}$ & Yes & Yes & Yes & 7 \\
\hline 4041 & No & & & Yes & Yes & 3 \\
\hline 4053 & & & & Yes & Yes & 14 \\
\hline 4074 & No & & Yes & Yes & Yes & 14 \\
\hline 5005 & No & & & Yes & Yes & 7 \\
\hline 5010 & No & & & & Yes & 3 \\
\hline 5011 & No & & & Yes & Yes & 7 \\
\hline
\end{tabular}


Operational Characteristics, Part 1 (cont.)

\begin{tabular}{|c|c|c|c|c|c|c|}
\hline TRS ID & Zones & $\begin{array}{l}\text { Number } \\
\text { of Zones }\end{array}$ & $\begin{array}{l}\text { Coordinate } \\
\text { Zones }\end{array}$ & $\begin{array}{l}\text { Standing } \\
\text { Reserv. }\end{array}$ & $\begin{array}{l}\text { Advanced } \\
\text { Reserv. }\end{array}$ & $\begin{array}{l}\text { Longest } \\
\text { Notice }\end{array}$ \\
\hline 5017 & No & & $\mathrm{N} / \mathrm{A}$ & Yes & Yes & 14 \\
\hline 5032 & Yes & 11 & Yes & Yes & Yes & 7 \\
\hline 5050 & No & $\mathrm{N} / \mathrm{A}$ & & Yes & Yes & 7 \\
\hline 5058 & No & & Yes & Yes & Yes & 14 \\
\hline 5066 & No & $\mathrm{N} / \mathrm{A}$ & $\mathrm{N} / \mathrm{A}$ & Yes & Yes & Next day \\
\hline 5117 & No & $\mathrm{N} / \mathrm{A}$ & & No & Yes & 14 \\
\hline 5119 & No & & $\mathrm{N} / \mathrm{A}$ & Yes & Yes & 8 \\
\hline 6008 & No & & Yes & No & Yes & 1 \\
\hline 6011 & No & & $\mathrm{N} / \mathrm{A}$ & Yes & Yes & 7 \\
\hline 6018 & No & $\mathrm{N} / \mathrm{A}$ & $\mathrm{N} / \mathrm{A}$ & Yes & Yes & 7 \\
\hline 6024 & No & & $\mathrm{N} / \mathrm{A}$ & No & Yes & 14 \\
\hline 6041 & No & & $\mathrm{N} / \mathrm{A}$ & Yes & Yes & 6 \\
\hline 6056 & No & 0 & No & Yes & Yes & 4 \\
\hline 6082 & No & & Yes & Yes & Yes & 5 \\
\hline 7001 & No & & & Yes & Yes & 7 \\
\hline 7006 & No & 6 & Yes & Yes & Yes & 7 \\
\hline 7015 & No & $\mathrm{N} / \mathrm{A}$ & & Yes & Yes & 7 \\
\hline 7035 & No & & Yes & No & Yes & 14 \\
\hline 8001 & $\mathrm{No}$ & & & Yes & Yes & 7 \\
\hline 8006 & No & $\mathrm{N} / \mathrm{A}$ & Yes & Yes & Yes & 3 \\
\hline 8011 & No & & & Yes & Yes & 14 \\
\hline 9001 & No & $\mathrm{N} / \mathrm{A}$ & Yes & Yes & Yes & 7 \\
\hline 9002 & No & $\mathrm{N} / \mathrm{A}$ & $\mathrm{N} / \mathrm{A}$ & Yes & Yes & $7-14$ \\
\hline 9008 & No & & $\mathrm{N} / \mathrm{A}$ & No & Yes & 6 \\
\hline 9010 & No & & & Yes & Yes & 1 \\
\hline 9028 & Yes & 3 & Yes & Yes & Yes & 7 \\
\hline 9029 & No & $\mathrm{N} / \mathrm{A}$ & & No & Yes & 14 \\
\hline 9030 & No & $\mathrm{N} / \mathrm{A}$ & $\mathrm{N} / \mathrm{A}$ & No & Yes & 14 \\
\hline 9032 & $\mathrm{No}$ & & & Yes & Yes & 14 \\
\hline 9034 & No & & & Yes & Yes & $\begin{array}{l}14 \mathrm{ADA}, \\
7 \mathrm{NON}-\mathrm{ADA}\end{array}$ \\
\hline 9036 & No & & $\mathrm{N} / \mathrm{A}$ & Yes & Yes & 7 \\
\hline 9062 & Yes & 2 & Yes & Yes & Yes & 14 \\
\hline 9078 & No & & & Yes & Yes & 2 \\
\hline 9089 & No & $\mathrm{N} / \mathrm{A}$ & $\mathrm{N} / \mathrm{A}$ & Yes & Yes & 7 \\
\hline 9090 & No & & & Yes & No & \\
\hline 9121 & No & $\mathrm{N} / \mathrm{A}$ & & Yes & Yes & 1 \\
\hline 9166 & Yes & 6 & Yes & Yes & No & \\
\hline 9185 & Yes & 4 & Yes & Yes & Yes & 2 \\
\hline
\end{tabular}


Operational Characteristics, Part 2

\begin{tabular}{|c|c|c|c|c|c|c|}
\hline TRS ID & $\begin{array}{l}\text { Same-Day } \\
\text { Requests }\end{array}$ & $\begin{array}{l}\text { Shortest } \\
\text { Notice }\end{array}$ & $\begin{array}{l}\text { Outside } \\
\text { Boundaries }\end{array}$ & $\begin{array}{l}\text { \%Directly } \\
\text { Operated }\end{array}$ & $\begin{array}{l}\text { Contract } \\
\text { Pay Basis }\end{array}$ & $\begin{array}{l}\text { Driver } \\
\text { Status }\end{array}$ \\
\hline 0008 & No & & $\mathrm{No}$ & $0 \%$ & hours & Indep. contract. \\
\hline 0029 & Yes & 1-2 hours & Yes & $0 \%$ & hours & Indep. contract. \\
\hline 1003 & $\begin{array}{l}\text { Yes (not } \\
\text { guaranteed) }\end{array}$ & immediate & Yes & $0 \%$ & $\begin{array}{l}\text { other (per } \\
\text { completed trip } \\
\text { route, fuel) }\end{array}$ & Indep. contract. \\
\hline 1049 & No & & Yes & $100 \%$ & $\mathrm{~N} / \mathrm{A}$ & Employees \\
\hline 2004 & No & 1 day before & No & $100 \%$ & $\mathrm{~N} / \mathrm{A}$ & Employees \\
\hline 2008 & & & Yes & $0 \%$ & hours & Indep. contract. \\
\hline 2080 & & & No & $0 \%$ & hours & Indep. contract. \\
\hline 2086 & Sometimes & & Yes & $100 \%$ & & Employees \\
\hline 3018 & No & 24 hours & Yes & $0 \%$ & requests & Employees \\
\hline 3022 & Yes & ASAP & Yes & $0 \%$ & hours & $\begin{array}{l}\text { Depends on the } \\
\text { provider - lots } \\
\text { dedicated vehicles } \\
\text { and taxis used }\end{array}$ \\
\hline 3025 & No & $\mathrm{N} / \mathrm{A}$ & Yes & $100 \%$ & hours & Employees \\
\hline 3030 & No & & Yes & $65 \%$ & $\begin{array}{l}\text { requests, hours } \\
\text { requests, hours }\end{array}$ & Indep. contract. \\
\hline 3034 & No & & No & $19 \%$ & hours & $\begin{array}{l}\text { Direct are } \\
\text { employees, } \\
\text { contractors } \\
\text { are not }\end{array}$ \\
\hline 3044 & No & 24 hours & Yes & $0 \%$ & mileage & Indep. contract. \\
\hline 4001 & Yes & 5 minutes & Yes & $100 \%$ & $\mathrm{~N} / \mathrm{A}$ & Employees \\
\hline 4008 & No & & Yes & $100 \%$ & $\mathrm{~N} / \mathrm{A}$ & Employees \\
\hline 4012 & Yes & & Yes & $100 \%$ & $\mathrm{~N} / \mathrm{A}$ & $\begin{array}{l}\text { Union - so } \\
\text { they fall } \\
\text { under the } \\
\text { management } \\
\text { of ATC }\end{array}$ \\
\hline 4019 & Yes & 1 hour & Yes & $100 \%$ & $\mathrm{~N} / \mathrm{A}$ & Employees \\
\hline 4022 & No & & No & $100 \%$ & $\mathrm{~N} / \mathrm{A}$ & Employees \\
\hline 4024 & No & & No & & & Employees \\
\hline 4026 & No & & Yes & & requests, mileage & Both \\
\hline
\end{tabular}


Operational Characteristics, Part 2 (cont.)

\begin{tabular}{|c|c|c|c|c|c|c|}
\hline TRS ID & $\begin{array}{l}\text { Same-Day } \\
\text { Requests }\end{array}$ & $\begin{array}{l}\text { Shortest } \\
\text { Notice }\end{array}$ & $\begin{array}{l}\text { Outside } \\
\text { Boundaries }\end{array}$ & $\begin{array}{l}\text { \%Directly } \\
\text { Operated }\end{array}$ & $\begin{array}{l}\text { Contract } \\
\text { Pay Basis }\end{array}$ & $\begin{array}{l}\text { Driver } \\
\text { Status }\end{array}$ \\
\hline 4029 & No & & Yes & $0 \%$ & requests & Employees \\
\hline 4035 & No & $\mathrm{N} / \mathrm{A}$ & Yes & $0 \%$ & requests & Indep. contract. \\
\hline 4041 & No & & No & $100 \%$ & $\mathrm{~N} / \mathrm{A}$ & $\mathrm{N} / \mathrm{A}$ \\
\hline 4053 & No & next day & & $100 \%$ & $\mathrm{~N} / \mathrm{A}$ & Employees \\
\hline 4074 & Yes & 2 hours & Yes & $80 \%$ & mileage & Both \\
\hline 5005 & No & & No & $28 \%$ & requests, hours & Both \\
\hline 5010 & Yes & & Yes & $67 \%$ & requests & $\begin{array}{l}\text { Employees } \\
\text { for DO and } \\
\text { Indep. contract. } \\
\text { for PT }\end{array}$ \\
\hline 5011 & Yes & 2 hours & Yes & $100 \%$ & & Employees \\
\hline 5017 & No & $\mathrm{N} / \mathrm{A}$ & No & $100 \%$ & $\mathrm{~N} / \mathrm{A}$ & Employees \\
\hline 5032 & Yes & 1 hour & Yes & $100 \%$ & & Employees \\
\hline 5050 & No & & Yes & $55 \%$ & hours & Employees \\
\hline 5058 & Yes & & No & $100 \%$ & & Employees \\
\hline 5066 & No & $\mathrm{N} / \mathrm{A}$ & No & & requests & Indep. contract. \\
\hline 5117 & No & 48 hours & Yes & $97 \%$ & hours & Employees \\
\hline 5119 & No & & Yes & $0 \%$ & hours, mileage & $\begin{array}{l}\text { Neither employees } \\
\text { or contractor }\end{array}$ \\
\hline 6008 & No & & & $0 \%$ & & Indep. contract. \\
\hline 6011 & No & $\begin{array}{l}\text { 4:45pm on } \\
\text { previous day }\end{array}$ & No & $50 \%$ & hours & Both \\
\hline 6018 & No & $\mathrm{N} / \mathrm{A}$ & No & $56 \%$ & hours & Indep. contract. \\
\hline 6024 & Yes & 15 minutes & Yes & $0 \%$ & hours & Indep. contract. \\
\hline 6041 & Yes & 3 hours & No & $50-60 \%$ & requests & Both \\
\hline 6056 & No & $\mathrm{N} / \mathrm{A}$ & No & $0 \%$ & $\begin{array}{l}\text { hours, monthly } \\
\text { fixed cost }\end{array}$ & Indep. contract. \\
\hline 6082 & No & & $\mathrm{N} / \mathrm{A}$ & $100 \%$ & & Employees \\
\hline 7001 & Yes & 30 minutes & No & $75 \%$ & requests, hours & $\begin{array}{l}\text { Employees } \\
\text { for DO and } \\
\text { Indep. contract. } \\
\text { for PT }\end{array}$ \\
\hline 7006 & Yes & ASAP & Yes & $100 \%$ & $\mathrm{~N} / \mathrm{A}$ & Employees \\
\hline 7015 & No & $\mathrm{N} / \mathrm{A}$ & Yes & $30 \%$ & requests & Employees \\
\hline
\end{tabular}


Operational Characteristics, Part 2 (cont.)

\begin{tabular}{|c|c|c|c|c|c|c|}
\hline TRS ID & $\begin{array}{l}\text { Same-Day } \\
\text { Requests }\end{array}$ & $\begin{array}{l}\text { Shortest } \\
\text { Notice }\end{array}$ & $\begin{array}{l}\text { Outside } \\
\text { Boundaries }\end{array}$ & $\begin{array}{l}\text { \%Directly } \\
\text { Operated }\end{array}$ & $\begin{array}{l}\text { Contract } \\
\text { Pay Basis }\end{array}$ & $\begin{array}{l}\text { Driver } \\
\text { Status }\end{array}$ \\
\hline 7035 & No & & Yes & & hours & Indep. contract. \\
\hline 8001 & Yes & 2 hours & Yes & $66 \%$ & hours & Employees \\
\hline 8006 & $\begin{array}{l}\text { Only in } \\
\text { case of } \\
\text { emergency }\end{array}$ & No time limit & No & $0 \%$ & Revenue hours & Employees \\
\hline 8011 & No & next day & Yes & $66 \%$ & requests & Employees \\
\hline 9001 & Yes-a few & same day & Yes & $0 \%$ & hours, mileage & Both \\
\hline 9002 & Yes & when ready & Yes & $98 \%$ & mileage & $\begin{array}{l}\text { Contracted } \\
\text { service }\end{array}$ \\
\hline 9008 & Yes & $\begin{array}{l}\text { they can try } \\
\text { for } 15 \mathrm{~min}\end{array}$ & Yes & $0 \%$ & hours & Indep. contract. \\
\hline 9010 & Yes & 20 minutes & No & $0 \%$ & mileage & Both \\
\hline 9028 & Yes & 2 hours & No & $0 \%$ & $\begin{array}{l}\text { hours, mileage } \\
\text { plus fixed monthly } \\
\text { expense }\end{array}$ & Employees \\
\hline 9029 & Yes & varies & Yes & $0 \%$ & $\begin{array}{l}\text { Actual cost plus } \\
\text { fixed fee }\end{array}$ & Employees \\
\hline 9030 & Yes & $\begin{array}{l}\text { whatever } \\
\text { available }\end{array}$ & No & $0 \%$ & hours, mileage & Indep. contract. \\
\hline 9032 & Yes & 2 hours & Yes & & hours & Employees \\
\hline 9034 & Yes & $\begin{array}{l}\text { up to } 2 \text { hours } \\
\text { prior to pick } \\
\text { up wanted }\end{array}$ & Yes & $100 \%$ & $\mathrm{~N} / \mathrm{A}$ & Employees \\
\hline 9036 & No & & Yes & $0 \%$ & hours & Indep. contract. \\
\hline 9062 & No & & Yes & $0 \%$ & hours & Indep. contract. \\
\hline 9078 & Yes & if possible & Yes & $0 \%$ & hours & Indep. contract. \\
\hline 9089 & No & next day & No & $100 \%$ & hours & Employees \\
\hline 9090 & Yes & $\begin{array}{l}\text { depends on } \\
\text { the vehicle } \\
\text { that will do } \\
\text { the trip. }\end{array}$ & Yes & $0 \%$ & hours, mileage & Indep. contract. \\
\hline 9121 & No & $\mathrm{N} / \mathrm{A}$ & Yes & $0 \%$ & Vehicle hours & Indep. contract. \\
\hline 9166 & No & next day & No & $0 \%$ & $\begin{array}{l}\text { requests, hours, } \\
\text { mileage }\end{array}$ & yes \\
\hline 9185 & $\begin{array}{l}\text { Yes (if } \\
\text { space } \\
\text { available) }\end{array}$ & 1 day & No & $0 \%$ & hours & Indep. contract. \\
\hline
\end{tabular}


Operational Characteristics, Part 3

\begin{tabular}{|c|c|c|c|}
\hline \multirow{2}{*}{$\frac{\text { TRS ID }}{0008}$} & \%Cancelled & $\% \mathrm{No}-\mathrm{show}$ & Return trip for no-show \\
\hline & & & \\
\hline 0029 & $21 \%$ & $2 \%$ & $\begin{array}{l}\text { automatically cancel return trip unless hear from cus- } \\
\text { tomer for the service }\end{array}$ \\
\hline 1003 & & & Per FTA guideline, return trip is kept in the schedule. \\
\hline 1049 & $15 \%$ & $3-5 \%$ & We honor the request for all return rides \\
\hline 2004 & $0.89 \%$ & $1.5 \%$ & $\begin{array}{l}\text { Customer has to call us if he/she doesn't want return } \\
\text { trip }\end{array}$ \\
\hline 2008 & $7 \%$ & $3.3 \%$ & $\begin{array}{l}\text { The carrier must verify that the return trip is not re- } \\
\text { quired prior to canceling the return trip. }\end{array}$ \\
\hline 2080 & $20 \%$ & $2 \%$ & Return trips remain scheduled. \\
\hline 2086 & $10-12 \%$ & $1 \%$ & \\
\hline 3018 & & $2 \%$ & $\begin{array}{l}\text { returned trip is generally attempted unless notification } \\
\text { is received }\end{array}$ \\
\hline 3022 & $11 \%$ & $2.5 \%$ & \\
\hline 3025 & less than $1 \%$ & less than $1 \%$ & Using radio communication, cancellations are made. \\
\hline 3030 & $11.8 \%$ & $10.8 \%$ & $\begin{array}{l}\text { A vehicle is sent for the outbound reservation. If the } \\
\text { customer is not available, then it is treated as 'no-show'. }\end{array}$ \\
\hline 3034 & & & The ride is rescheduled and may be an hour delay \\
\hline 3044 & $5 \%$ & $1 \%$ & Return ship is canceled \\
\hline 4001 & $2 \%$ & $0.5 \%$ & We don't cancel return trip unless client cancels. \\
\hline 4008 & $15 \%$ & $0.9 \%$ & $\begin{array}{l}\text { Depends: if customer no-shows (cancels), we cancel re- } \\
\text { turn. }\end{array}$ \\
\hline 4012 & & & We cancel the return trip \\
\hline 4019 & $10 \%$ & $3 \%$ & $\begin{array}{l}\text { Upon notification by passenger that the trip is not } \\
\text { needed, return trip is canceled. }\end{array}$ \\
\hline 4022 & $10 \%$ & $1.4 \%$ & $\begin{array}{l}\text { Reservation is maintained unless we are advised differ- } \\
\text { ently. }\end{array}$ \\
\hline 4024 & $5 \%$ & $10 \%$ & \\
\hline 4026 & $10 \%$ & $10 \%$ & No \\
\hline 4029 & $3 \%$ & $6 \%$ & Cancel return trip unless requested otherwise. \\
\hline 4035 & $14 \%$ & $4 \%$ & $\begin{array}{l}\text { ADA - return trip is provided unless customer contact } \\
\text { verifies to cancel return. Other funding sources, return } \\
\text { trip is automatically canceled. }\end{array}$ \\
\hline
\end{tabular}


Operational Characteristics, Part 3 (cont.)

\begin{tabular}{|c|c|c|c|}
\hline TRS ID & \%Cancelled & $\% \mathrm{No}-\mathrm{show}$ & Return trip for no-show \\
\hline 4041 & $11 \%$ & $1-5 \%$ & Trip stands until customer cancels \\
\hline 4053 & & & \\
\hline 4074 & $1 \%$ & $2 \%$ & $\begin{array}{l}\text { Call customer to inquire if they need return trip. If we } \\
\text { do not reach customer, reservation remains on schedule. }\end{array}$ \\
\hline 5005 & $10 \%$ & $2.4 \%$ & $\begin{array}{l}\text { Cancel return trip automatically until customer calls to } \\
\text { confirm. Then trip is added back in, on question asked. }\end{array}$ \\
\hline 5010 & $8 \%$ & less than $1 \%$ & Cancel it \\
\hline 5011 & $9 \%$ & $2 \%$ & $\begin{array}{l}\text { Cancel the trip if they don't call or we can't get a hold } \\
\text { of them. }\end{array}$ \\
\hline 5017 & $18 \%$ & $1.5 \%$ & $\begin{array}{l}\text { Efforts are made to contact customer. If unsuccessful, } \\
\text { the customer must call to retain any other trip that day. }\end{array}$ \\
\hline 5032 & $15 \%$ & $5 \%$ & The return trip is provided unless the customer cancels \\
\hline 5050 & $25 \%$ & $3 \%$ & $\begin{array}{l}\text { Cancel return trip. It will be reinstated at customer's } \\
\text { request. }\end{array}$ \\
\hline 5058 & $0.01 \%$ & $0.03 \%$ & $\begin{array}{l}\text { Call client and leave the return trip scheduled unless } \\
\text { contact with client for a cancellation. }\end{array}$ \\
\hline 5066 & $20 \%$ & $2 \%$ & Goes no customer's record. After 6 in a month, warning \\
\hline 5117 & $6.6 \%$ & $3.5 \%$ & Entire trip is canceled \\
\hline 5119 & $20 \%$ & $8 \%$ & Yes \\
\hline 6008 & $9 \%$ & $6 \%$ & Do not cancel (return trip scheduled separately) \\
\hline 6011 & less than $5 \%$ & $4 \%$ & $\begin{array}{l}\text { Return trip canceled one hour after no-show unless cus- } \\
\text { tomer calls to say they still want the return trip. }\end{array}$ \\
\hline 6018 & $28 \%$ & $4 \%$ & $\begin{array}{l}\text { We send another vehicle as we cannot strand them away } \\
\text { from home }\end{array}$ \\
\hline 6024 & $9 \%$ & $2.8 \%$ & $\begin{array}{l}\text { We keep the reservation, unless we are told to cancel or } \\
\text { we have contract with rider to verify the need. }\end{array}$ \\
\hline 6041 & $6 \%$ & $2 \%$ & $\begin{array}{l}\text { We cancel the return trip unless passenger notifies us } \\
\text { otherwise. }\end{array}$ \\
\hline 6056 & $10.5 \%$ & $3.3 \%$ & Return trips are carried out as scheduled. \\
\hline 6082 & $25 \%$ & $25 \%$ & Return trip is canceled \\
\hline 7001 & $1 \%$ & $0.5 \%$ & Cancel return. \\
\hline 7006 & $14.4 \%$ & $3.7 \%$ & The return trip is canceled immediately. \\
\hline
\end{tabular}


Operational Characteristics, Part 3 (cont.)

\begin{tabular}{|c|c|c|c|}
\hline TRS ID & \%Cancelled & $\% \mathrm{No}-\mathrm{show}$ & Return trip for no-show \\
\hline 7015 & $5 \%$ & $3 \%$ & We do not automatically cancel the return trip. \\
\hline 7035 & $7 \%$ & less than $1 \%$ & We automatically delete the return trip. \\
\hline 8001 & $13 \%$ & $17 \%$ & $\begin{array}{l}\text { Call dispatch to request possible route changes or for } \\
\text { possible same-day pickup calls }\end{array}$ \\
\hline 8006 & $12 \%$ & $6 \%$ & $\begin{array}{l}\text { We keep the trip scheduled. The client would need to } \\
\text { call and cancel. }\end{array}$ \\
\hline 8011 & & & Cancel off the schedule and cancel out the trip \\
\hline 9001 & $23 \%$ & $2-3 \%$ & $\begin{array}{l}\text { We keep the return trip reservation (unless customer } \\
\text { cancels it) and deal with it under the no-show policy if } \\
\text { both trips are no-shows. }\end{array}$ \\
\hline 9002 & & & Ride service as requested \\
\hline 9008 & $9 \%$ & $3.5 \%$ & Phone to see if something happened to the client. \\
\hline 9010 & & & \\
\hline 9028 & $11 \%$ & $9 \%$ & Progressive letters of warning up to service refusal \\
\hline 9029 & $3.9 \%$ & $6 \%$ & The reservation remains unchanged and is serviced. \\
\hline 9030 & unknown & unknown & cancel \\
\hline 9032 & $10-15 \%$ & $4 \%$ & We don't cancel the return request. \\
\hline 9034 & $18 \%$ & $5 \%$ & $\begin{array}{l}\text { ADA - not canceled unless contact with customer is } \\
\text { made first. NON-ADA return trip is canceled. }\end{array}$ \\
\hline 9036 & $4 \%$ & $3 \%$ & Customer must cancel return trip in order to avoid a \\
\hline 9062 & $24 \%$ & $5 \%$ & $\begin{array}{l}\text { no-show. } \\
\text { Return trip stays unless customer is reached and con- } \\
\text { firms there is no return trip }\end{array}$ \\
\hline \multicolumn{4}{|r|}{$\cos _{0}$} \\
\hline 9089 & $8 \%$ & $2 \%$ & $\begin{array}{l}\text { Attempt to contact customer throughout day to see if } \\
\text { return ride is still needed }\end{array}$ \\
\hline 9090 & $15 \%$ & $12 \%$ & return becomes cancelation \\
\hline 9121 & $17 \%$ & $5 \%$ & \\
\hline 9166 & $7 \%$ & $6.95 \%$ & It is the rider's responsibility to cancel the trip. \\
\hline 9185 & $6 \%$ & $2-3 \%$ & $\begin{array}{l}\text { Each trip is independently booked. So the reservation } \\
\text { remains scheduled. }\end{array}$ \\
\hline
\end{tabular}


Operational Characteristics, Part 4

\begin{tabular}{|c|c|c|}
\hline TRS ID & Impact of $\mathrm{No}^{-}$-show & Comment \\
\hline 0008 & No impact & Temporary suspension no-show policy \\
\hline 0029 & Letter & Two warning letters and then 2 week suspension \\
\hline 1003 & No impact & $\begin{array}{l}\text { Policy under review, educational compaign will be final } \\
\text { step. }\end{array}$ \\
\hline 1049 & Letter & Possible suspension after 3 in a 30 day period \\
\hline 2004 & Postcard & \\
\hline 2008 & & $\begin{array}{l}\text { Each time a customer no-shows or cancels late (af- } \\
\text { ter } 5 \mathrm{pm} \text { on the day before the ride is scheduled), it's } \\
\text { counted as a violation. A customer who has accumu- } \\
\text { lated } 7 \text { violations in } 6 \text { months or less is subject to hav- } \\
\text { ing his/her AAR service suspended for } 2 \text { weeks. Further } \\
\text { suspensions of } 3 \text { or } 4 \text { weeks within a } 12-\text { month period } \\
\text { may be assessed whether the number of violations re- } \\
\text { main excessive. }\end{array}$ \\
\hline 2080 & Letter & $\begin{array}{l}2 \text { no-shows within } 30 \text { days rolling window triggers warn- } \\
\text { ing letter. } 3 \text { no-shows within } 30 \text { days rolling window } \\
\text { triggers letter advising of temporary suspension of ser- } \\
\text { vice (generally } 1 \text { week), ability to appeal. }\end{array}$ \\
\hline 2086 & & 2 week suspension for 3 no show in a 30 day period \\
\hline 3018 & Letter & After 3 in a month, progressive discipline \\
\hline 3022 & Phone call and letter & No show policy includes potential suspension of service \\
\hline 3025 & Phone call & $\begin{array}{l}\text { If no-shows are frequent, clients are called and told that } \\
\text { if they do not cancel in advance, there is a chance ser- } \\
\text { vices will be terminated. }\end{array}$ \\
\hline 3030 & Letter & $\begin{array}{l}\text { Notices detailing the violations. When the customer has } \\
\text { reached the threshold (three no-show or six late cancel- } \\
\text { lations in a } 30 \text {-day period) a letter of suspension with } \\
\text { a copy of the appeals process is sent to the customer. }\end{array}$ \\
\hline 3034 & Phone call and letter & \\
\hline 3044 & Letter & Two written warnings, then a one month suspension \\
\hline
\end{tabular}


Operational Characteristics, Part 4 (cont.)

\begin{tabular}{|c|c|c|}
\hline TRS ID & Impact of No-show & Comment \\
\hline 4001 & Letter & \\
\hline 4008 & Letter & 4 letters in 30 days - suspension for 30 days \\
\hline 4012 & Letter & \\
\hline 4019 & Letter & \\
\hline 4022 & Letter & suspension \\
\hline 4024 & Letter & \\
\hline 4026 & Letter & \\
\hline 4029 & Letter & \\
\hline 4035 & Letter & suspension \\
\hline 4041 & Letter & $\begin{array}{l}3 \text { no-shows in } 30 \text { days result in suspension of service for } \\
30 \text { days. }\end{array}$ \\
\hline 4053 & Letter & \\
\hline 4074 & Phone call and letter & \\
\hline 5005 & Letter & \\
\hline 5010 & Letter & \\
\hline 5011 & Phone call & \\
\hline 5017 & Letter & \\
\hline 5032 & Letter & \\
\hline 5050 & Letter & $\begin{array}{l}\text { Impending suspension if } 4 \text { or more No-shows within a } \\
\text { calendar month. Appeal information is enclosed. }\end{array}$ \\
\hline 5058 & Phone call, letters & after 3 \\
\hline 5066 & Letter & \\
\hline 5117 & Letter & \\
\hline 5119 & No impact & $\begin{array}{l}\text { Currently, no impact. Procdure being put in place for } \\
\text { letter \& suspension. }\end{array}$ \\
\hline 6008 & Letter & if chronic \\
\hline 6011 & & $\begin{array}{l}\text { suspension if more than } 4 \text { no-shows during a calendar } \\
\text { month }\end{array}$ \\
\hline 6018 & Letter & $\begin{array}{l}\text { Warnings are given and if they no-show } 4 \text { times in a } 90 \\
\text { day period they risk being suspended for } 30 \text { days from } \\
\text { the program. }\end{array}$ \\
\hline 6024 & & $\begin{array}{l}4 \text { or more in one month: } 1 \text { week suspension; } 2 \text { nd offense: } \\
1 \text { month suspension; } 3 \text { rd offense: } 3 \text { month suspension; } \\
4 \text { th offense: } 6 \text { months suspension; start over each cal- } \\
\text { endar year in January. }\end{array}$ \\
\hline
\end{tabular}


Operational Characteristics, Part 4 (cont.)

\begin{tabular}{|c|c|c|}
\hline TRS ID & Impact of $\mathrm{No}^{-}$-show & Comment \\
\hline 6041 & Letter & $\begin{array}{l}\text { Can be suspended after } 2 \text { nd no-shows in a } 3 \text { month } \\
\text { period. }\end{array}$ \\
\hline 6056 & Letter & $\begin{array}{l}\text { suspension letter is sent after no-show policy is violated. } \\
30 \text { day suspension with } 3 \text { no-show in a rooling } 30 \text { day } \\
\text { period. } 7 \text { day suspension with cancellation of } 50 \% \text { or } \\
\text { more of scheduled trips. }\end{array}$ \\
\hline 6082 & & $\begin{array}{l}\text { No-show policy which can eventually lead to suspension } \\
\text { of service. }\end{array}$ \\
\hline 7001 & Letter & \\
\hline 7006 & Letter & $\begin{array}{l}\text { Points system administrated by sending letters leading } \\
\text { up to suspensions of service. }\end{array}$ \\
\hline 7015 & Letter & \\
\hline 7035 & Letter & Fee associated with each violation \\
\hline 8001 & Phone call and letter & Suspension of service \\
\hline 8006 & Letter & \\
\hline 8011 & & 3 strikes/month garners 1 week suspension \\
\hline 9001 & Letter & \\
\hline 9002 & Letter & 3 or more per month \\
\hline 9008 & Letter & ask to pay small penalty \\
\hline 9010 & Phone call & \\
\hline 9028 & Phone call and letter & \\
\hline 9029 & No impact & \\
\hline 9030 & other & Request payment sometimes \\
\hline 9032 & Letter & \\
\hline 9034 & Phone call and letter & after certain number of no shows \\
\hline 9036 & Letter & Letter after 2 in a month; suspension after 3 in a month \\
\hline 9062 & Phone call and letter & \\
\hline 9078 & & \\
\hline 9089 & No impact & $\begin{array}{l}\text { Currently, no impact. But, implementing policy FY06 } \\
\text { to deal with where customers will get both letters and } \\
\text { phone calls. }\end{array}$ \\
\hline 9090 & Letter & after 3 no-shows loss of 1 week service use \\
\hline 9121 & Letter & \\
\hline 9166 & Letter & \\
\hline 9185 & Letter & \\
\hline
\end{tabular}


Management Practices

\begin{tabular}{|c|c|c|c|c|c|c|}
\hline TRS ID & $\begin{array}{l}\text { Finacial } \\
\text { Penalties }\end{array}$ & $\begin{array}{l}\text { Finacial } \\
\text { Incentives }\end{array}$ & Ridesharing & $\begin{array}{l}\text { Agency } \\
\text { Admin. }\end{array}$ & $\begin{array}{l}\text { Contracted } \\
\text { Admin. }\end{array}$ & $\begin{array}{l}\text { Consumer } \\
\text { Choice }\end{array}$ \\
\hline 0008 & & & & $1985^{*}$ & & \\
\hline 0029 & $1997^{*}$ & & 1986 & 1990 & 1990 & \\
\hline 1003 & $1980^{*}$ & 1980* & 1977 & 1977 & & 1999 \\
\hline 1049 & $\mathrm{~N} / \mathrm{A}$ & N/A & $\mathrm{N} / \mathrm{A}$ & 2001 & $\mathrm{~N} / \mathrm{A}$ & $\mathrm{N} / \mathrm{A}$ \\
\hline 2004 & $\mathrm{~N} / \mathrm{A}$ & $\mathrm{N} / \mathrm{A}$ & & 1993 & $\mathrm{~N} / \mathrm{A}$ & $\mathrm{N} / \mathrm{A}$ \\
\hline 2008 & 1996 & 2001 & 1993 & 1993 & $\mathrm{~N} / \mathrm{A}$ & $\mathrm{N} / \mathrm{A}$ \\
\hline 2080 & 1993 & 2002 & 1993 & 1993 & 1993 & $\mathrm{~N} / \mathrm{A}$ \\
\hline 2086 & $\mathrm{~N} / \mathrm{A}$ & $\mathrm{N} / \mathrm{A}$ & 1978 & Yes & No & $\mathrm{N} / \mathrm{A}$ \\
\hline 3018 & 1996 & 1996 & 1981 & $1992 *$ & & \\
\hline 3022 & $1982^{*}$ & $\mathrm{~N} / \mathrm{A}$ & 1979 & $\mathrm{~N} / \mathrm{A}$ & 1979 & 1980 \\
\hline 3025 & & & Yes & 1991 & & \\
\hline 3030 & 2000 & 2000 & 1994 & 2000 & 1994 & $\mathrm{~N} / \mathrm{A}$ \\
\hline 3034 & 2004 & 2004 & & 1978 & & 2004 \\
\hline 3044 & & & $1994 *$ & $1992^{*}$ & & \\
\hline 4001 & $\mathrm{~N} / \mathrm{A}$ & $\mathrm{N} / \mathrm{A}$ & $\mathrm{N} / \mathrm{A}$ & 1980 & $\mathrm{~N} / \mathrm{A}$ & $\mathrm{N} / \mathrm{A}$ \\
\hline 4008 & $\mathrm{~N} / \mathrm{A}$ & $\mathrm{N} / \mathrm{A}$ & 1981 & 1981 & $\mathrm{~N} / \mathrm{A}$ & $\mathrm{N} / \mathrm{A}$ \\
\hline 4012 & $\mathrm{~N} / \mathrm{A}$ & $\mathrm{N} / \mathrm{A}$ & $\mathrm{N} / \mathrm{A}$ & $1990^{*}$ & $\mathrm{~N} / \mathrm{A}$ & $\mathrm{N} / \mathrm{A}$ \\
\hline 4019 & $\mathrm{~N} / \mathrm{A}$ & $\mathrm{N} / \mathrm{A}$ & 1978 & 1978 & $\mathrm{~N} / \mathrm{A}$ & $\mathrm{N} / \mathrm{A}$ \\
\hline 4022 & $\mathrm{~N} / \mathrm{A}$ & $\mathrm{N} / \mathrm{A}$ & $\mathrm{N} / \mathrm{A}$ & 1997 & $\mathrm{~N} / \mathrm{A}$ & $\mathrm{N} / \mathrm{A}$ \\
\hline 4024 & & $\mathrm{~N} / \mathrm{A}$ & 1989 & 1983 & $\mathrm{~N} / \mathrm{A}$ & \\
\hline 4026 & & & & 1998 & & \\
\hline 4029 & 2001 & 2001 & & 1996 & 1996 & 1996 \\
\hline 4035 & 1996 & 2002 & 1992 & 1992 & 1992 & $\mathrm{~N} / \mathrm{A}$ \\
\hline 4041 & $\mathrm{~N} / \mathrm{A}$ & $\mathrm{N} / \mathrm{A}$ & $\mathrm{N} / \mathrm{A}$ & 2000 & $\mathrm{~N} / \mathrm{A}$ & $\mathrm{N} / \mathrm{A}$ \\
\hline 4053 & $\mathrm{~N} / \mathrm{A}$ & $\mathrm{N} / \mathrm{A}$ & yes & yes & No & No \\
\hline 4074 & $\mathrm{~N} / \mathrm{A}$ & $\mathrm{N} / \mathrm{A}$ & $\mathrm{N} / \mathrm{A}$ & 1997 & $\mathrm{~N} / \mathrm{A}$ & $\mathrm{N} / \mathrm{A}$ \\
\hline 5005 & 1980 & No & 1980 & 1980 & No & No \\
\hline 5010 & 1995 & & & $1975^{*}$ & & \\
\hline 5011 & $\mathrm{~N} / \mathrm{A}$ & $\mathrm{N} / \mathrm{A}$ & 1991 & 1991 & $\mathrm{~N} / \mathrm{A}$ & $\mathrm{N} / \mathrm{A}$ \\
\hline 5017 & $\mathrm{~N} / \mathrm{A}$ & $\mathrm{N} / \mathrm{A}$ & $\mathrm{N} / \mathrm{A}$ & N/A & $\mathrm{N} / \mathrm{A}$ & $\mathrm{N} / \mathrm{A}$ \\
\hline 5032 & $\mathrm{~N} / \mathrm{A}$ & $\mathrm{N} / \mathrm{A}$ & $\mathrm{N} / \mathrm{A}$ & $1980^{*}$ & $\mathrm{~N} / \mathrm{A}$ & $\mathrm{N} / \mathrm{A}$ \\
\hline 5050 & 2000 & & 2005 & 1990 & $\mathrm{~N} / \mathrm{A}$ & $\mathrm{N} / \mathrm{A}$ \\
\hline 5058 & $\mathrm{~N} / \mathrm{A}$ & $\mathrm{N} / \mathrm{A}$ & $\mathrm{N} / \mathrm{A}$ & Yes & No & No \\
\hline 5066 & 1996 & 1996 & & & 1996 & 1996 \\
\hline
\end{tabular}


Management Practices (cont.)

\begin{tabular}{|c|c|c|c|c|c|c|}
\hline TRS ID & $\begin{array}{l}\text { Finacial } \\
\text { Penalties }\end{array}$ & $\begin{array}{l}\text { Finacial } \\
\text { Incentives }\end{array}$ & Ridesharing & $\begin{array}{l}\text { Agency } \\
\text { Admin. }\end{array}$ & $\begin{array}{l}\text { Contracted } \\
\text { Admin. }\end{array}$ & $\begin{array}{l}\text { Consumer } \\
\text { Choice }\end{array}$ \\
\hline 5117 & 1985 & $\mathrm{~N} / \mathrm{A}$ & 1992 & 1984 & $\mathrm{~N} / \mathrm{A}$ & $\mathrm{N} / \mathrm{A}$ \\
\hline 5119 & 2005 & 2005 & $\mathrm{~N} / \mathrm{A}$ & 1997 & $\mathrm{~N} / \mathrm{A}$ & $\mathrm{N} / \mathrm{A}$ \\
\hline 6008 & $1985^{*}$ & $1990 *$ & 1979 & 1979 & 1979 & \\
\hline 6011 & & & 1988 & 1980 & & \\
\hline 6018 & $1999^{*}$ & & & $1999^{*}$ & $1999^{*}$ & $\mathrm{~N} / \mathrm{A}$ \\
\hline 6024 & $\mathrm{~N} / \mathrm{A}$ & $\mathrm{N} / \mathrm{A}$ & $\mathrm{N} / \mathrm{A}$ & 1981 & 1981 & $\mathrm{~N} / \mathrm{A}$ \\
\hline 6041 & 2002 & & 1981 & 1981 & & \\
\hline 6056 & 1994 & 1994 & $1990 *$ & 1995 & 1994 & $\mathrm{~N} / \mathrm{A}$ \\
\hline 6082 & $\mathrm{~N} / \mathrm{A}$ & $\mathrm{N} / \mathrm{A}$ & 1983 & 1983 & $\mathrm{~N} / \mathrm{A}$ & $\mathrm{N} / \mathrm{A}$ \\
\hline 7001 & $\mathrm{~N} / \mathrm{A}$ & $\mathrm{N} / \mathrm{A}$ & 1972 & 1972 & $1985^{*}$ & $\mathrm{~N} / \mathrm{A}$ \\
\hline 7006 & 1987 & $\mathrm{~N} / \mathrm{A}$ & & & & \\
\hline 7015 & $\mathrm{~N} / \mathrm{A}$ & $\mathrm{N} / \mathrm{A}$ & $1986^{*}$ & $1990^{*}$ & $1990^{*}$ & $\mathrm{~N} / \mathrm{A}$ \\
\hline 7035 & 1990 & & 1990 & & 1980 & \\
\hline 8001 & 1996 & 2003 & 1999 & 1996 & 1996 & \\
\hline 8006 & 2002 & 2002 & 1996 & 1996 & 1996 & $\mathrm{~N} / \mathrm{A}$ \\
\hline 8011 & & & & 1997 & & \\
\hline 9001 & $1995^{*}$ & $1995^{*}$ & 1988 & 1988 & 1988 & $\mathrm{~N} / \mathrm{A}$ \\
\hline 9002 & & & & yes & & \\
\hline 9008 & not yet & & always & no & no & no \\
\hline 9010 & 2004 & 2003 & $1990^{*}$ & 2000 & $2000^{*}$ & 2000 \\
\hline 9028 & 1996 & 1996 & $\mathrm{~N} / \mathrm{A}$ & 1996 & 1980 & none \\
\hline 9029 & $1988^{*}$ & $1988^{*}$ & $1976^{*}$ & 1976 & $1976^{*}$ & \\
\hline 9030 & & & & 1995 & 1992 & \\
\hline 9032 & 2001 & 2001 & & 1975 & & \\
\hline 9034 & & & 1975 & 1975 & $\mathrm{~N} / \mathrm{A}$ & $\mathrm{N} / \mathrm{A}$ \\
\hline 9036 & $1976^{*}$ & $1976^{*}$ & $1976^{*}$ & 1995 & $1976^{*}$ & $\mathrm{~N} / \mathrm{A}$ \\
\hline 9062 & $1999^{*}$ & $\mathrm{~N} / \mathrm{A}$ & $1991^{*}$ & $1991^{*}$ & 1991 & $\mathrm{~N} / \mathrm{A}$ \\
\hline \multicolumn{7}{|l|}{9078} \\
\hline 9089 & & & $1994^{*}$ & 1990 & 1990 & \\
\hline 9090 & & & & & $1996^{*}$ & \\
\hline 9121 & 1992 & 1992 & 1992 & 1996 & 1992 & $\mathrm{~N} / \mathrm{A}$ \\
\hline 9166 & 1994 & 1994 & 1994 & $\mathrm{~N} / \mathrm{A}$ & 1994 & $\mathrm{~N} / \mathrm{A}$ \\
\hline 9185 & 1995 & 1995 & 1995 & 1997 & 1995 & $\mathrm{~N} / \mathrm{A}$ \\
\hline
\end{tabular}


Implementation of Financial Penalties/Incentives, Part 1

\begin{tabular}{|c|c|c|c|}
\hline TRS ID & $\begin{array}{l}\text { Measures for } \\
\text { Incentives }\end{array}$ & Other measures & Incentives Awarded \\
\hline 0008 & Other & $\begin{array}{l}\text { Availability of operators to } \\
\text { perform route }\end{array}$ & \\
\hline \multicolumn{4}{|l|}{0029} \\
\hline 1003 & $\begin{array}{l}\text { On-time pick-ups, } \\
\text { Customer complaints, } \\
\text { Other }\end{array}$ & $\begin{array}{l}\text { accidents, communication failures, } \\
\text { uniform }\end{array}$ & Monthly \\
\hline 1049 & $\mathrm{~N} / \mathrm{A}$ & & $\mathrm{N} / \mathrm{A}$ \\
\hline 2004 & $\mathrm{~N} / \mathrm{A}$ & & $\mathrm{N} / \mathrm{A}$ \\
\hline 2008 & $\begin{array}{l}\text { On-time pick-ups, } \\
\text { Other }\end{array}$ & no-show rates & \\
\hline 2080 & $\begin{array}{l}\text { On-time pick-ups, } \\
\text { Productivity, } \\
\text { Other }\end{array}$ & $\begin{array}{l}\text { customer service, safety, } \\
\text { and operator excellence }\end{array}$ & $\begin{array}{l}\text { weekly for on-time pickup, } \\
\text { monthly, annually, } \\
\text { depending on the individual } \\
\text { incentive }\end{array}$ \\
\hline $\begin{array}{l}2086 \\
3018\end{array}$ & $\mathrm{~N} / \mathrm{A}$ & & \\
\hline 3022 & $\begin{array}{l}\text { On-time pick-ups, } \\
\text { Productivity, } \\
\text { Customer complaints }\end{array}$ & $\begin{array}{l}\text { Compliance with other requirement, } \\
\text { cost/productivity }\end{array}$ & \\
\hline 3025 & No incentives & & $\mathrm{N} / \mathrm{A}$ \\
\hline 3030 & $\begin{array}{l}\text { On-time pick-ups, } \\
\text { Other }\end{array}$ & $\begin{array}{l}\text { FTA drug, alcohol compliance, } \\
\text { Telephone response time }\end{array}$ & Monthly \\
\hline 3034 & $\begin{array}{l}\text { On-time pick-ups, } \\
\text { Productivity, } \\
\text { Driver turnover, } \\
\text { Other }\end{array}$ & On-time pullouts & Monthly \\
\hline $\begin{array}{l}3044 \\
4001 \\
4008 \\
4012\end{array}$ & & & \\
\hline $\begin{array}{l}4019 \\
4022\end{array}$ & $\mathrm{~N} / \mathrm{A}$ & & $\mathrm{N} / \mathrm{A}$ \\
\hline 4024 & On-time pick-ups & & Yearly \\
\hline 4026 & $\mathrm{~N} / \mathrm{A}$ & & Never \\
\hline 4029 & Customer complaints & & Monthly \\
\hline
\end{tabular}


Implementation of Financial Penalties/Incentives, Part 1 (cont.)

\begin{tabular}{|c|c|c|c|}
\hline TRS ID & $\begin{array}{l}\text { Measures for } \\
\text { Incentives }\end{array}$ & Other measures & Incentives Awarded \\
\hline 4035 & $\begin{array}{l}\text { Customer complaints, } \\
\text { Other }\end{array}$ & Call hold time & Quarterly \\
\hline \multicolumn{4}{|l|}{4041} \\
\hline 4053 & None & & $\mathrm{N} / \mathrm{A}$ \\
\hline 4074 & None & & $\mathrm{N} / \mathrm{A}$ \\
\hline 5005 & No & & \\
\hline \multicolumn{4}{|l|}{5010} \\
\hline 5011 & No & & No \\
\hline \multicolumn{4}{|l|}{5017} \\
\hline \multicolumn{4}{|l|}{5032} \\
\hline \multicolumn{4}{|l|}{5050} \\
\hline 5058 & $\mathrm{~N} / \mathrm{A}$ & $\mathrm{N} / \mathrm{A}$ & $\mathrm{N} / \mathrm{A}$ \\
\hline 5066 & $\begin{array}{l}\text { On-time pick-ups, } \\
\text { Productivity }\end{array}$ & & Monthly \\
\hline \multicolumn{4}{|l|}{5117} \\
\hline 5119 & $\begin{array}{l}\text { On-time pick-ups, } \\
\text { Productivity, } \\
\text { Customer complaints, } \\
\text { Other }\end{array}$ & $\begin{array}{l}\text { Missed trips, long trips, } \\
\text { vehicle maintenance, uniform, } \\
\text { qualifications, accident reports, } \\
\text { use of vehicles }\end{array}$ & Monthly \\
\hline 6008 & $\begin{array}{l}\text { Customer complaints, } \\
\text { Other }\end{array}$ & accidents & \\
\hline 6011 & None & & $\mathrm{N} / \mathrm{A}$ \\
\hline \multicolumn{4}{|l|}{6018} \\
\hline 6041 & $\mathrm{~N} / \mathrm{A}$ & & $\mathrm{N} / \mathrm{A}$ \\
\hline 6056 & $\mathrm{~N} / \mathrm{A}$ & & $\mathrm{N} / \mathrm{A}$ \\
\hline \multicolumn{4}{|l|}{6082} \\
\hline \multicolumn{4}{|l|}{7001} \\
\hline \multicolumn{4}{|l|}{7006} \\
\hline \multicolumn{4}{|l|}{7015} \\
\hline \multicolumn{4}{|l|}{7035} \\
\hline 8001 & Productivity & & Annually \\
\hline 8006 & $\begin{array}{l}\text { On-time pick-ups, } \\
\text { Productivity, } \\
\text { Customer complaints }\end{array}$ & & Monthly \\
\hline
\end{tabular}


Implementation of Financial Penalties/Incentives, Part 1 (cont.)

\begin{tabular}{|c|c|c|c|}
\hline TRS ID & $\begin{array}{l}\text { Measures for } \\
\text { Incentives }\end{array}$ & Other measures & Incentives Awarded \\
\hline \multicolumn{4}{|l|}{8011} \\
\hline 9001 & $\begin{array}{l}\text { On-time pick-ups, } \\
\text { Productivity, } \\
\text { Customer complaints, } \\
\text { Other }\end{array}$ & $\begin{array}{l}\text { no-shows, phone hold time, } \\
\text { road calls, preventable accidents }\end{array}$ & Quarterly \\
\hline \multicolumn{4}{|l|}{9002} \\
\hline 9008 & None & & \\
\hline 9010 & Other & for disabled patrons & $\begin{array}{l}\$ 1.00 \text { for every disabled } \\
\text { patron trip is billed } \\
\text { on invoices }\end{array}$ \\
\hline \multicolumn{4}{|l|}{9028} \\
\hline 9029 & Other & $\begin{array}{l}\text { Telephone performance, } \\
\text { manitenance performance }\end{array}$ & Monthly \\
\hline \multicolumn{4}{|c|}{ 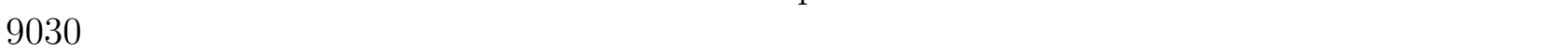 } \\
\hline 9032 & $\begin{array}{l}\text { On-time pick-ups, } \\
\text { Productivity, } \\
\text { Customer complaints, } \\
\text { Other }\end{array}$ & Safety, accident per 100,000 miles & Monthly and quarterly \\
\hline \multicolumn{4}{|l|}{9034} \\
\hline $\begin{array}{l}9036 \\
9062\end{array}$ & Productivity & & None to date \\
\hline 9078 & $\begin{array}{l}\text { On-time pick-ups, } \\
\text { Productivity, } \\
\text { Customer complaints }\end{array}$ & & Monthly \\
\hline \multicolumn{4}{|l|}{9089} \\
\hline 9090 & $\begin{array}{l}\text { Customer complaints, } \\
\text { Driver turnover }\end{array}$ & & Every 6 months \\
\hline 9121 & Productivity & & Monthly \\
\hline 9166 & On-time pick-ups & & Monthly \\
\hline 9185 & $\begin{array}{l}\text { On-time pick-ups } \\
\text { Productivity, } \\
\text { Other }\end{array}$ & $\begin{array}{l}\text { Vehicle cleanliness, no-shows, } \\
\text { late cancellations, } \\
\text { failure to pass CHP inspection, } \\
\text { abandon call ratio, failure to } \\
\text { provide obligation in the scope } \\
\text { of work. }\end{array}$ & $\begin{array}{l}\text { Based on verification, } \\
\text { either paid or } \\
\text { deducted from invoices }\end{array}$ \\
\hline
\end{tabular}


Implementation of Financial Penalties/Incentives, Part 2

\begin{tabular}{|c|c|c|c|}
\hline TRS ID & $\begin{array}{l}\text { Measures for } \\
\text { Penalties }\end{array}$ & Other measures & Penalties Assessed \\
\hline 0008 & Other & $\begin{array}{l}\text { Availability of operators to } \\
\text { perform route }\end{array}$ & \\
\hline 0029 & Other & Not reporting accidents & one or twice a year \\
\hline 1003 & $\begin{array}{l}\text { On-time pick-ups, } \\
\text { Customer complaints, } \\
\text { Other }\end{array}$ & $\begin{array}{l}\text { accidents, communication failures, } \\
\text { uniform }\end{array}$ & Monthly \\
\hline 1049 & $\mathrm{~N} / \mathrm{A}$ & & \\
\hline 2004 & & & \\
\hline 2008 & & & \\
\hline 2080 & $\begin{array}{l}\text { On-time pick-ups, } \\
\text { Customer complaints }\end{array}$ & & $\begin{array}{l}\text { As warranted per contract - } \\
\text { periodically and upon } \\
\text { upon instances of } \\
\text { non-compliance }\end{array}$ \\
\hline 2086 & & & \\
\hline 3018 & $\begin{array}{l}\text { On-time pick-ups, } \\
\text { Customer complaints }\end{array}$ & & Monthly \\
\hline 3022 & Productivity & & Quarterly \\
\hline 3025 & No penalties & & $\mathrm{N} / \mathrm{A}$ \\
\hline 3030 & $\begin{array}{l}\text { On-time pick-ups, } \\
\text { Other }\end{array}$ & $\begin{array}{l}\text { FTA drug, alcohol compliance, } \\
\text { Telephone response time }\end{array}$ & Monthly if necessary \\
\hline 3034 & $\begin{array}{l}\text { On-time pick-ups, } \\
\text { Productivity, } \\
\text { Driver turnover, } \\
\text { Other }\end{array}$ & $\begin{array}{l}\text { Driver out of uniform, incomplete } \\
\text { manifest, missing manifest, } \\
\text { vehicle maintenance PM }\end{array}$ & Monthly \\
\hline \multicolumn{4}{|l|}{3044} \\
\hline \multicolumn{4}{|l|}{4001} \\
\hline \multicolumn{4}{|l|}{4008} \\
\hline \multicolumn{4}{|l|}{4012} \\
\hline 4019 & $\mathrm{~N} / \mathrm{A}$ & & $\mathrm{N} / \mathrm{A}$ \\
\hline \multicolumn{4}{|l|}{4022} \\
\hline 4024 & On-time pick-ups & & \\
\hline 4026 & $\mathrm{~N} / \mathrm{A}$ & & Never \\
\hline 4029 & On-time pick-ups & & Monthly \\
\hline & Customer complaints & & \\
\hline 4035 & $\begin{array}{l}\text { On-time pick-ups, } \\
\text { Customer complaints, } \\
\text { Other }\end{array}$ & Call hold time & Quarterly \\
\hline
\end{tabular}


Implementation of Financial Penalties/Incentives, Part 2 (cont.)

\begin{tabular}{|c|c|c|c|}
\hline TRS ID & $\begin{array}{l}\text { Measures for } \\
\text { Penalties }\end{array}$ & Other measures & Penalties Assessed \\
\hline \multicolumn{4}{|l|}{4041} \\
\hline 4053 & $\mathrm{~N} / \mathrm{A}$ & & $\mathrm{N} / \mathrm{A}$ \\
\hline 4074 & $\mathrm{~N} / \mathrm{A}$ & & $\mathrm{N} / \mathrm{A}$ \\
\hline 5005 & On-time pick-ups & & Monthly \\
\hline 5010 & On-time pick-ups & & Monthly \\
\hline 5011 & No & & \\
\hline \multicolumn{4}{|l|}{5017} \\
\hline \multicolumn{4}{|l|}{5032} \\
\hline 5050 & $\begin{array}{l}\text { On-time pick-ups, } \\
\text { Customer complaints }\end{array}$ & & Monthly \\
\hline \multicolumn{4}{|l|}{5058} \\
\hline 5066 & $\begin{array}{l}\text { On-time pick-ups, } \\
\text { Productivity }\end{array}$ & & Monthly \\
\hline \multicolumn{4}{|l|}{5117} \\
\hline 5119 & $\begin{array}{l}\text { On-time pick-ups, } \\
\text { Productivity, } \\
\text { Customer complaints, } \\
\text { Other }\end{array}$ & $\begin{array}{l}\text { Missed trips, long trips, } \\
\text { vehicle maintenance, uniform, } \\
\text { qualifications, accident reports, } \\
\text { use of vehicles }\end{array}$ & Monthly \\
\hline 6008 & Driver turnover & & \\
\hline 6011 & Other & $\begin{array}{l}\text { Failure to perform scheduled runs; } \\
\text { abandonment of 'at risk' customers }\end{array}$ & very seldom \\
\hline $\begin{array}{l}6018 \\
6024\end{array}$ & On-time pick-ups & & \\
\hline 6041 & $\begin{array}{l}\text { On-time pick-ups, } \\
\text { Other }\end{array}$ & Late paperwork & $\begin{array}{l}\text { As they occur, } \\
\text { very few each month }\end{array}$ \\
\hline 6056 & $\begin{array}{l}\text { On-time pick-ups, } \\
\text { Driver turnover }\end{array}$ & & Monthly \\
\hline $\begin{array}{l}6082 \\
7001 \\
7006 \\
7015\end{array}$ & & & \\
\hline 7035 & $\begin{array}{l}\text { On-time pick-ups, } \\
\text { Productivity }\end{array}$ & $\begin{array}{l}\text { We have not had to penalize the } \\
\text { contractor at this time. } \\
\text { However, we have initiated several } \\
\text { warning letters. }\end{array}$ & \\
\hline
\end{tabular}


Implementation of Financial Penalties/Incentives, Part 2 (cont.)

\begin{tabular}{|c|c|c|c|}
\hline TRS ID & $\begin{array}{l}\text { Measures for } \\
\text { Penalties }\end{array}$ & Other measures & Penalties Assessed \\
\hline 8001 & Productivity & & Annually \\
\hline 8006 & $\begin{array}{l}\text { On-time pick-ups, } \\
\text { Productivity, } \\
\text { Customer complaints }\end{array}$ & & Monthly \\
\hline \multicolumn{4}{|l|}{8011} \\
\hline 9001 & $\begin{array}{l}\text { On-time pick-ups, } \\
\text { Productivity, } \\
\text { Customer complaints, } \\
\text { Other }\end{array}$ & $\begin{array}{l}\text { no-shows, phone hold time, } \\
\text { road calls, preventable accidents }\end{array}$ & Quarterly \\
\hline \multicolumn{4}{|l|}{9002} \\
\hline 9008 & Other & missing service & not yet \\
\hline $\begin{array}{l}9010 \\
9028\end{array}$ & Customer complaints & & Monthly \\
\hline 9029 & Other & $\begin{array}{l}\text { Telephone performance, } \\
\text { manitenance performance }\end{array}$ & Monthly \\
\hline \multicolumn{4}{|l|}{9030} \\
\hline 9032 & $\begin{array}{l}\text { On-time pick-ups, } \\
\text { Customer complaints }\end{array}$ & & Monthly \\
\hline \multicolumn{4}{|l|}{9034} \\
\hline 9036 & $\begin{array}{l}\text { Customer complaints, } \\
\text { Other }\end{array}$ & Maintenance, missed service & \\
\hline 9062 & $\begin{array}{l}\text { On-time pick-ups, } \\
\text { Productivity }\end{array}$ & & rarely \\
\hline 9078 & $\begin{array}{l}\text { On-time pick-ups, } \\
\text { Productivity, } \\
\text { Customer complaints }\end{array}$ & & Monthly \\
\hline $\begin{array}{l}9089 \\
9090\end{array}$ & & & \\
\hline 9121 & Productivity & & Monthly \\
\hline 9166 & On-time pick-ups & & Monthly \\
\hline 9185 & $\begin{array}{l}\text { On-time pick-ups, } \\
\text { Productivity, } \\
\text { Other }\end{array}$ & $\begin{array}{l}\text { Vehicle cleanliness, no-shows, } \\
\text { late cancellations, failure to } \\
\text { pass CHP inspection, abandon call } \\
\text { ratio, failure to provide } \\
\text { obligation in the scope of work. }\end{array}$ & Monthly if needed \\
\hline
\end{tabular}




\begin{tabular}{|c|c|c|}
\hline \multicolumn{3}{|c|}{$\begin{array}{l}\text { Implementation of Financial } \\
\text { Penalties/Incentives, Part } 3\end{array}$} \\
\hline \multirow[b]{3}{*}{ TRS ID } & \multicolumn{2}{|c|}{ On-time Window } \\
\hline & Earliest & Latest \\
\hline & Arrival & Arrival \\
\hline 0008 & 0 & 30 \\
\hline 0029 & 15 & 15 \\
\hline 1003 & & 0 \\
\hline 1049 & 15 & 15 \\
\hline 2004 & 15 & 15 \\
\hline 2008 & 0 & 30 \\
\hline 2080 & 20 & 20 \\
\hline 2086 & 60 & 15 \\
\hline 3018 & 15 & 15 \\
\hline 3022 & 10 & 20 \\
\hline 3025 & 15 & 15 \\
\hline 3030 & 15 & 15 \\
\hline 3034 & 0 & 30 \\
\hline 3044 & 15 & 15 \\
\hline 4001 & 15 & 15 \\
\hline 4008 & & \\
\hline 4012 & 20 & 20 \\
\hline 4019 & 10 & 10 \\
\hline 4022 & & 30 \\
\hline 4024 & 15 & 15 \\
\hline 4026 & 15 & 15 \\
\hline 4029 & 15 & 15 \\
\hline 4035 & 15 & 15 \\
\hline 4041 & & \\
\hline 4053 & 30 & 30 \\
\hline 4074 & 60 & 0 \\
\hline 5005 & 0 & 20 \\
\hline 5010 & 20 & 20 \\
\hline 5011 & 60 & 60 \\
\hline 5017 & 10 & 20 \\
\hline 5032 & & \\
\hline 5050 & 15 & 15 \\
\hline 5058 & 15 & 15 \\
\hline 5066 & & 5 \\
\hline
\end{tabular}




\begin{tabular}{|c|c|c|}
\hline \multicolumn{3}{|c|}{$\begin{array}{l}\text { Implementation of Financial } \\
\text { Penalties/Incentives, Part } 3 \text { (cont.) }\end{array}$} \\
\hline \multirow[b]{3}{*}{ TRS ID } & \multicolumn{2}{|c|}{ On-time Window } \\
\hline & Earliest & Latest \\
\hline & Arrival & Arrival \\
\hline 5117 & 20 & 20 \\
\hline 5119 & 10 & 10 \\
\hline 6008 & 15 & 15 \\
\hline 6011 & 0 & 20 \\
\hline 6018 & 15 & 15 \\
\hline 6024 & 15 & 15 \\
\hline 6041 & 15 & 15 \\
\hline 6056 & 0 & 20 \\
\hline 6082 & 15 & 15 \\
\hline 7001 & 15 & 15 \\
\hline 7006 & 15 & 15 \\
\hline 7015 & 60 & 60 \\
\hline 7035 & 15 & 15 \\
\hline 8001 & 20 & 20 \\
\hline 8006 & 15 & 15 \\
\hline 8011 & 15 & 15 \\
\hline 9001 & 15 & 15 \\
\hline 9002 & 0 & 30 \\
\hline 9008 & 0 & 15 \\
\hline 9010 & & 25 \\
\hline 9028 & 15 & 15 \\
\hline 9029 & 10 & 30 \\
\hline 9030 & 3 & 10 \\
\hline 9032 & 0 & 30 \\
\hline 9034 & 15 & 15 \\
\hline 9036 & 5 & 15 \\
\hline 9062 & 15 & 15 \\
\hline 9078 & 30 & 30 \\
\hline 9089 & & 30 \\
\hline 9090 & 15 & 15 \\
\hline 9121 & 0 & 20 \\
\hline 9166 & 0 & 20 \\
\hline 9185 & 5 & 10 \\
\hline
\end{tabular}


Advanced Technologies

\begin{tabular}{|c|c|c|c|c|c|}
\hline TRS ID & $\begin{array}{l}\text { Advanced } \\
\text { Communications }\end{array}$ & $\begin{array}{l}\text { Advanced } \\
\text { Vehicle } \\
\text { Location }\end{array}$ & $\begin{array}{l}\text { Auto. } \\
\text { Fare } \\
\text { Payment }\end{array}$ & $\begin{array}{l}\text { Auto. } \\
\text { Transit } \\
\text { Information }\end{array}$ & $\begin{array}{l}\text { Paratransit } \\
\text { CAD }\end{array}$ \\
\hline 0008 & & $1996^{*}$ & & & $1993^{*}$ \\
\hline 0029 & $1997^{*}$ & $\mathrm{~N} / \mathrm{A}$ & $\mathrm{N} / \mathrm{A}$ & $\mathrm{N} / \mathrm{A}$ & 1994 \\
\hline 1003 & 1999 & $2004(12)$ & $\begin{array}{l}\text { middle } \\
\text { from } \\
1998-2004\end{array}$ & $2005(1)$ & $2004(12)$ \\
\hline 1049 & 2001 & $\mathrm{~N} / \mathrm{A}$ & $\mathrm{N} / \mathrm{A}$ & $\mathrm{N} / \mathrm{A}$ & 2001 \\
\hline 2004 & 1995 & 1996 & $\mathrm{~N} / \mathrm{A}$ & 2001 & 1995 \\
\hline 2008 & $\mathrm{~N} / \mathrm{A}$ & $\mathrm{N} / \mathrm{A}$ & $\mathrm{N} / \mathrm{A}$ & $\mathrm{N} / \mathrm{A}$ & $1996^{*}$ \\
\hline 2080 & 1993 & 2002 & & & $2001^{*}$ \\
\hline 2086 & 2004 & 2005 & & 2005 & 2005 \\
\hline 3018 & 1992 & & & & \\
\hline 3022 & $\mathrm{~N} / \mathrm{A}$ & $\mathrm{N} / \mathrm{A}$ & $\mathrm{N} / \mathrm{A}$ & $\mathrm{N} / \mathrm{A}$ & $2001^{*}$ \\
\hline 3025 & & & & & Yes \\
\hline 3030 & 1994 & 2000 & $\mathrm{~N} / \mathrm{A}$ & $\mathrm{N} / \mathrm{A}$ & 2000 \\
\hline 3034 & 2001 & 2001 & 2001 & 2005 & 2001 \\
\hline 3044 & & & & & \\
\hline 4001 & 1980 & $\mathrm{~N} / \mathrm{A}$ & $\mathrm{N} / \mathrm{A}$ & $\mathrm{N} / \mathrm{A}$ & 1991 \\
\hline 4008 & $\mathrm{~N} / \mathrm{A}$ & 1999 & $\mathrm{~N} / \mathrm{A}$ & $\mathrm{N} / \mathrm{A}$ & 1993 \\
\hline 4012 & $1995^{*}$ & $1995^{*}$ & & 2004 & $1995^{*}$ \\
\hline 4019 & 1978 & 2001 & $\mathrm{~N} / \mathrm{A}$ & $\mathrm{N} / \mathrm{A}$ & 2001 \\
\hline 4022 & 1997 & Soon & Soon & $\mathrm{N} / \mathrm{A}$ & $2000^{*}$ \\
\hline 4024 & & & & & \\
\hline 4026 & & & 2005 & & 2000 \\
\hline 4029 & & & & & 1996 \\
\hline 4035 & 1992 & $\mathrm{~N} / \mathrm{A}$ & $\mathrm{N} / \mathrm{A}$ & $\mathrm{N} / \mathrm{A}$ & 1992 \\
\hline 4041 & & & & & \\
\hline 4053 & 1997 & & & & 2003 \\
\hline 4074 & $\mathrm{~N} / \mathrm{A}$ & $\mathrm{N} / \mathrm{A}$ & $\mathrm{N} / \mathrm{A}$ & $\mathrm{N} / \mathrm{A}$ & 1999 \\
\hline 5005 & $\begin{array}{l}\text { 1975(simple radio) } \\
\text { 2004(MDT's) }\end{array}$ & 2004 & No & No & $1992^{*}$ \\
\hline 5010 & $1975^{*}$ & 2001 & 2001 & & 2001 \\
\hline 5011 & 1989 & $\mathrm{~N} / \mathrm{A}$ & $\mathrm{N} / \mathrm{A}$ & $\mathrm{N} / \mathrm{A}$ & 2003 \\
\hline 5017 & 1999 & 1999 & 2004 & 2003 & 1999 \\
\hline 5032 & $1980^{*}$ & $2006^{*}$ & $2007^{*}$ & $2006^{*}$ & 2004 \\
\hline 5050 & 2001 & $\mathrm{~N} / \mathrm{A}$ & $\mathrm{N} / \mathrm{A}$ & $\mathrm{N} / \mathrm{A}$ & 1996 \\
\hline
\end{tabular}


Advanced Technologies (cont.)

\begin{tabular}{|c|c|c|c|c|c|}
\hline TRS ID & $\begin{array}{l}\text { Advanced } \\
\text { Communications }\end{array}$ & $\begin{array}{l}\text { Advanced } \\
\text { Vehicle } \\
\text { Location }\end{array}$ & $\begin{array}{l}\text { Auto. } \\
\text { Fare } \\
\text { Payment }\end{array}$ & $\begin{array}{l}\text { Auto. } \\
\text { Transit } \\
\text { Information }\end{array}$ & $\begin{array}{l}\text { Paratransit } \\
\text { CAD }\end{array}$ \\
\hline 5058 & prior to 1991 & $\mathrm{~N} / \mathrm{A}$ & $\mathrm{N} / \mathrm{A}$ & $\mathrm{N} / \mathrm{A}$ & $\mathrm{N} / \mathrm{A}$ \\
\hline 5066 & & & & & 2005 pending \\
\hline 5117 & 2001 & 1999 & $\mathrm{~N} / \mathrm{A}$ & 1998 & 1994 \\
\hline 5119 & $\mathrm{~N} / \mathrm{A}$ & $2000^{*}$ & $\mathrm{~N} / \mathrm{A}$ & $\mathrm{N} / \mathrm{A}$ & 1997 \\
\hline 6008 & 1979 & 1993 & & & 1980 \\
\hline 6011 & 1981 & 2001 & & & $1991^{*}$ \\
\hline 6018 & 1998 & & & & 1998 \\
\hline 6024 & 1981 & $\mathrm{~N} / \mathrm{A}$ & $\mathrm{N} / \mathrm{A}$ & $\mathrm{N} / \mathrm{A}$ & 1996 \\
\hline 6041 & & & & & $2000^{*}$ \\
\hline 6056 & 1994 & 2001 & $\mathrm{~N} / \mathrm{A}$ & $\mathrm{N} / \mathrm{A}$ & 1997 \\
\hline 6082 & 1983 & 2001 & $\mathrm{~N} / \mathrm{A}$ & $\mathrm{N} / \mathrm{A}$ & 1999* \\
\hline 7001 & 1972 & & & & 1999* \\
\hline 7006 & 1995 & & & & 1993 \\
\hline 7015 & $1990 *$ & $\mathrm{~N} / \mathrm{A}$ & $\mathrm{N} / \mathrm{A}$ & $\mathrm{N} / \mathrm{A}$ & $\mathrm{N} / \mathrm{A}$ \\
\hline 7035 & 1980 & 2001 & & & 2001 \\
\hline 8001 & 2001 & 2003 & & & \\
\hline 8006 & $\mathrm{~N} / \mathrm{A}$ & $\mathrm{N} / \mathrm{A}$ & $\mathrm{N} / \mathrm{A}$ & $\mathrm{N} / \mathrm{A}$ & 1996 \\
\hline 8011 & $2001^{*}$ & $2001^{*}$ & & & $2001^{*}$ \\
\hline 9001 & 2003 & 2003 & $\mathrm{~N} / \mathrm{A}$ & $\mathrm{N} / \mathrm{A}$ & 1992 \\
\hline 9002 & yes & 2000 & & & 1998 \\
\hline 9008 & 2000 & & & & \\
\hline 9010 & 2001 & 2001 & 2001 & 2001 & 2001 \\
\hline 9028 & $\mathrm{~N} / \mathrm{A}$ & $\mathrm{N} / \mathrm{A}$ & $\mathrm{N} / \mathrm{A}$ & $\mathrm{N} / \mathrm{A}$ & $\mathrm{N} / \mathrm{A}$ \\
\hline 9029 & & & & & 1998 \\
\hline 9030 & $\mathrm{~N} / \mathrm{A}$ & $\mathrm{N} / \mathrm{A}$ & $\mathrm{N} / \mathrm{A}$ & $\mathrm{N} / \mathrm{A}$ & $\mathrm{N} / \mathrm{A}$ \\
\hline 9032 & 1975 & 2001 & & & 2000 \\
\hline 9034 & 2000 & 2003 & $\mathrm{~N} / \mathrm{A}$ & $\mathrm{N} / \mathrm{A}$ & 1991 \\
\hline 9036 & $1976^{*}$ & FY06 & $\mathrm{N} / \mathrm{A}$ & FY06 & 1995 \\
\hline 9062 & $1991^{*}$ & 2005 & $\mathrm{~N} / \mathrm{A}$ & $\mathrm{N} / \mathrm{A}$ & 1991 \\
\hline \multicolumn{6}{|l|}{9078} \\
\hline 9089 & & 2005 & & & 1994 \\
\hline 9090 & 1999* & & & & $2000^{*}$ \\
\hline 9121 & $\mathrm{~N} / \mathrm{A}$ & $\mathrm{N} / \mathrm{A}$ & $\mathrm{N} / \mathrm{A}$ & $\mathrm{N} / \mathrm{A}$ & $\mathrm{N} / \mathrm{A}$ \\
\hline 9166 & 1994 & 1996 & $\mathrm{~N} / \mathrm{A}$ & $\mathrm{N} / \mathrm{A}$ & 1994 \\
\hline 9185 & 1995 & $\mathrm{~N} / \mathrm{A}$ & $\mathrm{N} / \mathrm{A}$ & $\mathrm{N} / \mathrm{A}$ & yes \\
\hline
\end{tabular}


Uses of Computer-Aided Dispatching, Part 1

\begin{tabular}{|c|c|c|c|c|c|}
\hline TRS ID & $\begin{array}{l}\text { Routes } \\
\text { Grouped }\end{array}$ & $\begin{array}{l}\text { Manual } \\
\text { Revise } \\
\text { Before } \\
\text { Use }\end{array}$ & $\begin{array}{l}\text { Revised } \\
\text { During } \\
\text { Use }\end{array}$ & Comment & $\begin{array}{l}\text { How long planned } \\
\text { in advance }\end{array}$ \\
\hline 0008 & Automatically & Yes & Automatically & & \\
\hline 0029 & Both & Yes & Manually & $\begin{array}{l}\text { used to be } \\
\text { manually, } \\
\text { just migrated } \\
\text { to TRAPEZE4 }\end{array}$ & 7 days \\
\hline 1003 & $\begin{array}{l}\text { Manually }(10 \%) \text {, } \\
\text { Automatically } \\
(90 \%)\end{array}$ & Yes & Automatically & & \\
\hline 1049 & Automatically & Yes & Manually & & $\begin{array}{l}14 \text { days for subscription; } \\
2 \text { days for demand }\end{array}$ \\
\hline 2004 & Automatically & Yes & Manually & & The day before \\
\hline 2008 & Automatically & Yes & Both & & $\begin{array}{l}\text { A basic route matrix is } \\
\text { adjusted daily }\end{array}$ \\
\hline $\begin{array}{l}2080 \\
2086\end{array}$ & Automatically & Yes & Both & & $\begin{array}{l}\text { On-going and continuously } \\
\text { revised }\end{array}$ \\
\hline 3018 & Manually & & Manually & & \\
\hline 3022 & $\begin{array}{l}\text { Both, depends } \\
\text { on the } \\
\text { providers }\end{array}$ & Yes & Manually & & day in advance \\
\hline 3025 & Manually & & Manually & & The day before \\
\hline 3030 & Manually & Yes & Manually & & \\
\hline 3034 & Automatically & Yes & Both & & \\
\hline 3044 & Manually & & Manually & & \\
\hline 4001 & Automatically & Yes & Both & & 24 hours \\
\hline 4008 & Automatically & Yes & Both & & 5 days \\
\hline 4012 & Automatically & Yes & Manually & & 1 day \\
\hline 4019 & Automatically & Yes & Automatically & & 24 hours \\
\hline 4022 & Automatically & Yes & Both & & 7 days \\
\hline 4024 & Both & Yes & Manually & & \\
\hline
\end{tabular}


Uses of Computer-Aided Dispatching, Part 1 (cont.)

\begin{tabular}{|c|c|c|c|c|c|}
\hline TRS ID & $\begin{array}{l}\text { Routes } \\
\text { Grouped }\end{array}$ & $\begin{array}{l}\text { Manual } \\
\text { Revise } \\
\text { Before } \\
\text { Use }\end{array}$ & $\begin{array}{l}\text { Revised } \\
\text { During } \\
\text { Use }\end{array}$ & Comment & $\begin{array}{l}\text { How long planned } \\
\text { in advance }\end{array}$ \\
\hline 4026 & Both & Yes & Manually & & 2 weeks to 2 days \\
\hline 4029 & Automatically & Yes & Manually & & night before \\
\hline 4035 & Automatically & No & Both & & Evening prior to service \\
\hline 4041 & Automatically & Yes & Manually & & \\
\hline 4053 & Automatically & Yes & Manually & & 12 hours \\
\hline 4074 & Automatically & Yes & Manually & & day before service \\
\hline 5005 & Automatically & Yes & Both & & day before service \\
\hline 5010 & Automatically & No & Manually & & Less than 24 hours \\
\hline 5011 & Both & Yes & Both & & 7 days \\
\hline 5017 & Automatically & Yes & Automatically & & finalized day before \\
\hline 5032 & Automatically & No & Automatically & & \\
\hline 5050 & Automatically & Yes & Manually & & day before service \\
\hline $\begin{array}{l}5058 \\
5066\end{array}$ & Both & Yes & Manually & & 1 day \\
\hline 5117 & Automatically & Yes & Other & $\begin{array}{l}\text { use radio } \\
\text { with driver }\end{array}$ & \\
\hline 5119 & Automatically & Yes & Manually & & at least 30 days \\
\hline 6008 & Automatically & Yes & & & \\
\hline 6011 & $\begin{array}{l}\text { Manually } \\
\text { (subscriptions, } \\
35 \% \text { of trips) } \\
\text { Automatically } \\
\text { (non-subscript.) }\end{array}$ & Yes & Manually & $\begin{array}{l}\text { Scheduler } \\
\text { revise the } \\
\text { routes } \\
\text { before use }\end{array}$ & $\begin{array}{l}7 \text { days subscription, } \\
1 \text { day non-subscription }\end{array}$ \\
\hline 6018 & Both & Yes & Manually & & $\begin{array}{l}\text { The night before the route } \\
\text { is scheduled }\end{array}$ \\
\hline 6024 & Manually & Yes & Manually & & Up to two weeks \\
\hline 6041 & Manually & Yes & Manually & & 6 days \\
\hline 6056 & Automatically & Yes & Manually & & Up to 4 days in advance \\
\hline 6082 & Automatically & Yes & Manually & & 2 days \\
\hline
\end{tabular}


Uses of Computer-Aided Dispatching, Part 1 (cont.)

\begin{tabular}{|c|c|c|c|c|c|}
\hline TRS ID & $\begin{array}{l}\text { Routes } \\
\text { Grouped }\end{array}$ & $\begin{array}{l}\text { Manua } \\
\text { Revise } \\
\text { Before } \\
\text { Use }\end{array}$ & $\begin{array}{l}\text { Revised } \\
\text { During } \\
\text { Use }\end{array}$ & Comment & $\begin{array}{l}\text { How long planned } \\
\text { in advance }\end{array}$ \\
\hline 7001 & Automatically & Yes & Manually & & 24 hours \\
\hline 7006 & Automatically & Yes & Automatically & & $\begin{array}{l}\text { Routes are perfected the } \\
\text { day before service }\end{array}$ \\
\hline 7015 & Automatically & Yes & Automatically & & 24 hours \\
\hline 7035 & Automatically & Yes & Manually & & 24 hours \\
\hline 8001 & Manually & Yes & Manually & & daily-weekly-biweekly \\
\hline 8006 & Automatically & Yes & Automatically & & \\
\hline 8011 & Automatically & No & & & $\begin{array}{l}\text { The night before the route } \\
\text { is scheduled }\end{array}$ \\
\hline 9001 & Both & Yes & Manually & & $1-8$ days \\
\hline 9002 & Automatically & Yes & Manually & & Evening prior to service \\
\hline 9008 & Manually & & Manually & & \\
\hline 9010 & Automatically & No & Automatically & & \\
\hline 9028 & Manually & & Manually & & up to 7 days \\
\hline 9029 & Automatically & Yes & Manually & & 14 days \\
\hline 9030 & Automatically & Yes & Manually & & days before \\
\hline 9032 & Automatically & Yes & Manually & & \\
\hline 9034 & Both & Yes & Manually & & $\begin{array}{l}\text { up to } 2 \text { weeks in advance } \\
\text { for presheduled, but route } \\
\text { is built as day progresses } \\
\text { using same day requests }\end{array}$ \\
\hline 9036 & Automatically & Yes & Manually & & \\
\hline 9062 & Both & Yes & Manually & & night before \\
\hline 9078 & Automatically & Yes & Manually & & 14 days \\
\hline 9089 & Both & Yes & Manually & & \\
\hline 9090 & Manually & & & & \\
\hline 9121 & Both & Yes & Both & & afternoon before \\
\hline 9166 & Both & Yes & Manually & & \\
\hline 9185 & Both & Yes & Manually & & between one and two days \\
\hline
\end{tabular}


Uses of Computer-Aided Dispatching, Part 2

\begin{tabular}{|c|c|c|c|c|}
\hline TRS ID & $\begin{array}{l}\text { What } \\
\text { Period }\end{array}$ & $\begin{array}{l}\text { Other } \\
\text { Period }\end{array}$ & $\begin{array}{l}\text { Amount of } \\
\text { requests }\end{array}$ & $\begin{array}{l}\text { Other } \\
\text { Amount }\end{array}$ \\
\hline 0008 & $\begin{array}{l}\text { Full-day, } \\
\text { Half-day }\end{array}$ & & Full-day & \\
\hline 0029 & Full-day & & Full-day & \\
\hline 1003 & Other & $\begin{array}{l}\text { schedules are } \\
\text { created after } 4 \mathrm{pm} \\
\text { the day before } \\
\text { operations }\end{array}$ & Other & $\begin{array}{l}\text { several routes at } \\
\text { a time in sequences }\end{array}$ \\
\hline 1049 & Full-day & & Full-day & \\
\hline 2004 & Full-day & & Full-day & \\
\hline 2008 & Full-day & & Full-day & \\
\hline 2080 & Other & $\begin{array}{l}\text { various - } \\
\text { shifts are } \\
\text { generally } 4 \text { to } 9 \\
\text { hours in length }\end{array}$ & Other & Full route \\
\hline 2086 & & & & \\
\hline 3018 & Full-day & & $\begin{array}{l}\text { Full-day, } \\
\text { One-at-a-time }\end{array}$ & \\
\hline 3022 & Other & $\begin{array}{l}\text { Depends on the } \\
\text { provider }\end{array}$ & Other & $\begin{array}{l}\text { Depends on the } \\
\text { provider }\end{array}$ \\
\hline 3025 & Full-day & & Full-day & \\
\hline 3030 & Full-day & & Full-day & \\
\hline 3034 & Full-day & & Full-day & \\
\hline 3044 & Half-day & & Full-day & \\
\hline 4001 & Full-day & & Full-day & \\
\hline 4008 & Other & $\begin{array}{l}\text { various routes } \\
\text { from 5:30 am, } \\
\text { ends at 2:30 am }\end{array}$ & Other & \\
\hline 4012 & Full-day & & Other & 5 lines on the MDT \\
\hline 4019 & Full-day & & Other & 1 hour \\
\hline 4022 & Full-day & & Full-day & \\
\hline 4024 & Full-day & & Full-day & \\
\hline 4026 & Full-day & & Full-day & \\
\hline 4029 & Full-day & & Full-day & \\
\hline 4035 & Full-day & & Full-day & \\
\hline 4041 & Full-day & & Full-day & \\
\hline 4053 & Full-day & & Full-day & \\
\hline 4074 & Full-day & & Full-day & \\
\hline
\end{tabular}




\begin{tabular}{|c|c|c|c|c|}
\hline TRS ID & $\begin{array}{l}\text { What } \\
\text { Period }\end{array}$ & $\begin{array}{l}\text { Other } \\
\text { Period }\end{array}$ & $\begin{array}{l}\text { Amount of } \\
\text { requests }\end{array}$ & $\begin{array}{l}\text { Other } \\
\text { Amount }\end{array}$ \\
\hline 5005 & Full-day & & Full-day & \\
\hline 5010 & Full-day & $\begin{array}{l}\text { return trips are } \\
\text { added as they } \\
\text { occur }\end{array}$ & Full-day & $\begin{array}{l}\text { return trips are } \\
\text { added as they } \\
\text { occur }\end{array}$ \\
\hline 5011 & Full-day & & Full-day & \\
\hline 5017 & $\begin{array}{l}\text { Full-day, } \\
\text { Half-day }\end{array}$ & & Full-day & \\
\hline 5032 & Full-day & & Full-day & \\
\hline 5050 & Full-day & & Full-day & \\
\hline 5058 & Full-day & & Full-day & \\
\hline 5066 & & & & \\
\hline 5117 & Half-day & & Full-day & \\
\hline 5119 & Full-day & & Full-day & \\
\hline 6008 & & & & $2-3$ requests at a time \\
\hline 6011 & Half-day & & Full-day & $\begin{array}{l}\text { Full day on printed } \\
\log ; 2 \text { hours on MDT }\end{array}$ \\
\hline 6018 & Full-day & $\begin{array}{l}\text { We have } 4,6 \& \\
\text { 8-hour routes. }\end{array}$ & Full-day & $\begin{array}{l}\text { We give a paper } \\
\text { manifest for the } \\
\text { entire route whether } \\
\text { it is a full or } \\
\text { partial day. }\end{array}$ \\
\hline 6024 & Full-day & & Full-day & \\
\hline 6041 & Full-day & & Full-day & \\
\hline 6056 & Full-day & & Full-day & $\begin{array}{l}\text { with changes } \\
\text { throughout the day }\end{array}$ \\
\hline 6082 & $\begin{array}{l}\text { Full-day, } \\
\text { Half-day }\end{array}$ & & Full-day & \\
\hline 7001 & Full-day & & Full-day & \\
\hline 7006 & Full-day & $\begin{array}{l}6,8,10 \text {-hour } \\
\text { shifts }\end{array}$ & Full-day & $\begin{array}{l}\text { On a printed passenger } \\
\text { manifest and six stops } \\
\text { at-a-time on } \\
\text { Mobile data terminal. }\end{array}$ \\
\hline 7015 & Full-day & & Full-day & \\
\hline 7035 & Full-day & & Half day & \\
\hline 8001 & Full-day & & Half day & \\
\hline 8006 & Full-day & & Full-day & \\
\hline 8011 & Full-day & & Full-day & \\
\hline
\end{tabular}


Uses of Computer-Aided Dispatching, Part 2 (cont.)

\begin{tabular}{|c|c|c|c|c|}
\hline TRS ID & $\begin{array}{l}\text { What } \\
\text { Period }\end{array}$ & $\begin{array}{l}\text { Other } \\
\text { Period }\end{array}$ & $\begin{array}{l}\text { Amount of } \\
\text { requests }\end{array}$ & $\begin{array}{l}\text { Other } \\
\text { Amount }\end{array}$ \\
\hline 9001 & $\begin{array}{l}\text { Full-day, } \\
\text { Half-day }\end{array}$ & & $\begin{array}{l}\text { Full-day, } \\
\text { Half-day, } \\
\text { One-at-a-time }\end{array}$ & $\begin{array}{l}\text { one-at-a-time } \\
\text { (additions, cancels, } \\
\text { etc.) }\end{array}$ \\
\hline 9002 & Half-day & & Other & 8-hour shift \\
\hline 9008 & Full-day & & Full-day & \\
\hline 9010 & Full-day & & Other & $\begin{array}{l}\text { requests up to } 100-150 \\
\text { miles at one time }\end{array}$ \\
\hline 9028 & Full-day & & Full-day & \\
\hline 9029 & Full-day & & Full-day & \\
\hline 9030 & Full-day & & Full-day & \\
\hline 9032 & Half-day & & $\begin{array}{l}\text { Full-day, } \\
\text { Other }\end{array}$ & $\begin{array}{l}\text { one-at-a-time for } \\
\text { same-day requests }\end{array}$ \\
\hline 9034 & Other & $\begin{array}{l}\text { Service is } \\
\text { primarily same-day. } \\
\text { Route is planned } \\
\text { as requests } \\
\text { come in. }\end{array}$ & Other & $\begin{array}{l}\text { approx. } 1 \text { hour route } \\
\text { of trips is sent via } \\
\text { MDT }\end{array}$ \\
\hline 9036 & Full-day & & Full-day & $\begin{array}{l}\text { currently full--day, } \\
\text { beginning in FY06, } \\
\text { with implementation } \\
\text { of MDT units, will } \\
\text { give driver next } \\
\text { three to five stops }\end{array}$ \\
\hline 9062 & Full-day & & Full-day & \\
\hline 9078 & Full-day & & Full-day & \\
\hline 9089 & Full dau & & Full-day & \\
\hline 9090 & Full-day & & Full-day & \\
\hline 9121 & $\begin{array}{l}\text { Full-day, } \\
\text { Half-day }\end{array}$ & & $\begin{array}{l}\text { Full-day, } \\
\text { Half-day }\end{array}$ & \\
\hline 9166 & $\begin{array}{l}\text { Full-day, } \\
\text { Half-day }\end{array}$ & & $\begin{array}{l}\text { Full-day, } \\
\text { Half-day, } \\
\text { One-at-a-time }\end{array}$ & \\
\hline 9185 & $\begin{array}{l}\text { Full-day, } \\
\text { Half-day }\end{array}$ & & $\begin{array}{l}\text { Full-day, } \\
\text { Half-day, } \\
\text { One-at-a-time }\end{array}$ & $\begin{array}{l}\text { eg: Road calls for } \\
\text { passenger's } \\
\text { incidents/illnesses. }\end{array}$ \\
\hline
\end{tabular}

